
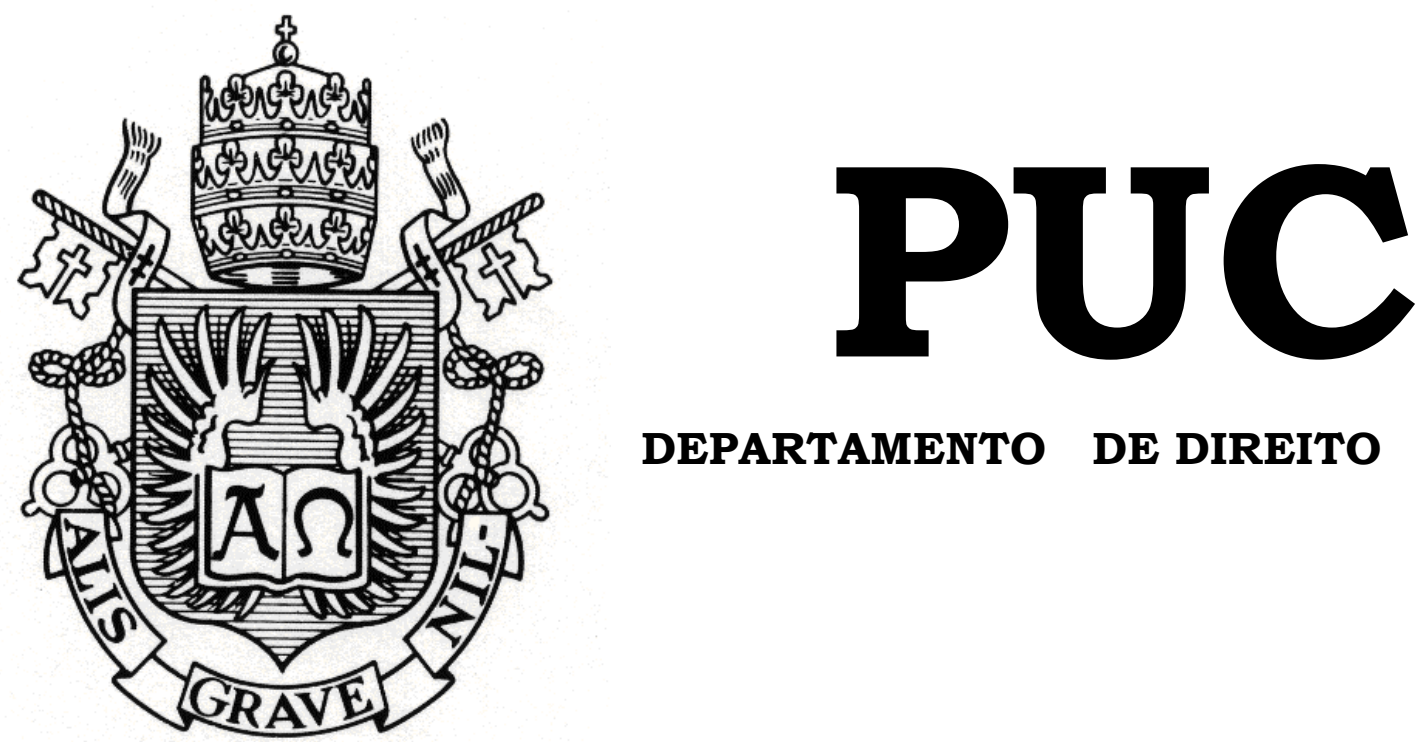

DEPARTAMENTO DE DIREITO

\title{
Justiça Transicional e Lei Anistia: o Julgamento do Caso Araguaia pela Corte
} Interamericana de Direitos Humanos.

por

FABIO DE ALMEIDA CASCARDO ORIENTADOR(A): CAROLINA DE CAMPOS
MELO

2009.2

PONTIFÍCIA UNIVERSIDADE CATÓLICA DO RIO DE JANEIRO 


\title{
Justiça Transicional e Lei de Anistia: o Julgamento do Caso Araguaia pela Corte Interamericana de Direitos Humanos.
}

\author{
por \\ FABIO DE ALMEIDA CASCARDO
}

Monografia apresentada ao Departamento de Direito da Pontificia Universidade Católica do Rio de Janeiro (PUC-Rio) para a obtenção do Título de Bacharel em Direito.

Orientador(a): Carolina de Campos Melo. 
"às aranhas"

Ana Luiza Beraba. América Aracnídea:

Teias culturais interamericanas 


\section{AGRADECIMENTOS}

Se existe a possibilidade das próximas páginas deste trabalho monográfico não contribuírem em grande medida para o dia-a-dia do direito, sem alterar, por consequiência, qualquer fato do cotidiano; é certo que nesta esta a maior oportunidade em toda a minha formação para falar com as pessoas para quem devo o meu agradecimento. Isso já é o bastante para tornar este trabalho um instrumento muito poderoso.

Alexandre Conti, Andrea Paleari, Cristiano Quintanilha, Eduardo Apfel, Gustavo Hirsch, Leandro Faria, Leonardo Fernandes, Mariana Meneguetti e Rodrigo Vecchi; pelo que aprendi, pelo que escutei e pelo que copiei. Com vocês pude falar abertamente, e por isso eu só posso agradecer.

Aos meus avós Isidoro, Idalina, Mauricio e Yolanda, pelo carinho incomum e pelas tantas histórias que, agora vejo, também falam sobre mim.

À minha família, não apenas pela diversidade de exemplos que encontro em cada um e no magnífico conjunto que formamos, mas ao meu pai, Ruy, minha mãe, Maria Eugenia e minha madrasta, Comba, por me darem as mãos desde o início e sempre.

E aos meus irmãos Mauricio, João Luiz, Mario e Alice, pelo retrato da infância, pelo companheirismo mais completo, pela convivência extraordinária e pelo espelho natural que sou de vocês.

Não poderia deixar de lembrar e agradecer muito os meus colegas do Grupo Simulações e Realidades e as Professoras Carolina de Campos Melo e Márcia Nina Bernardes, pelos nossos encontros, conquistas e oportunidades.

Muito Obrigado,

Fabio de A. Cascardo. 


\section{RESUMO}

O trabalho apresenta elementos de justiça transicional e estuda a jurisprudência da Corte Interamericana de Direitos Humanos sobre direito à verdade, incorporação de leis de auto-anistia e acesso à informação para analisar a demanda do Caso Julia Gomes Lund e outros vs. Brasil (Caso Araguaia), submetido ao julgamento deste Tribunal em 2009. Tal análise visa ressaltar os principais desafios que o caso representa à Corte e ao Estado brasileiro com relação ao direito à verdade, promulgação de leis de anistia e ainda sobre sigilo de documentos, levando em consideração a postura adotada pelo Brasil nos últimos 30 anos.

\section{ABSTRACT}

This work presents some transicional justice elements and studies the InterAmerican Court's jurisprudence concerning the right to truth, the incorporation of self-amnesty laws and the right of access to information to analyze the Case Julia Gomes Lund et al vs. Brazil (the Araguaia Guerrilla Movement), under appreciation of this Court since 2009. The analysis emphasizes the greater challenges that this case represents to the Court and to Brazil regarding the right to truth, the promulgation of self-amnesty laws and finally the policy that determines the secrecy of documents, taking into account the State's attitude on the last 30 years.

\section{PALAVRAS-CHAVE}

Direitos Humanos; Direito Internacional; Justiça Transicional; Sistema Interamericano; Corte Interamericana; Lei de Anistia; Auto-Anistia; Acesso à Informação; Direito à verdade; Araguaia. 


\section{SUMÁRIO:}

Introdução .7

Capítulo I - Justiça transicional na América Latina...................................10

A) Elementos da justiça transicional no continente......................13

B) Superação de falsas dicotomias para momentos de transição....16

Capítulo II - O Sistema Interamericano de Proteção dos Direitos

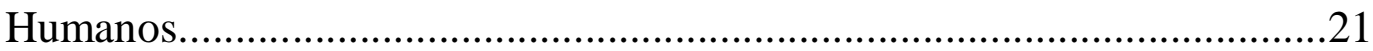

A) Órgãos de Proteção dos Direitos Humanos no Sistema.............21

B) Obrigações Internacionais dos Estados no Sistema

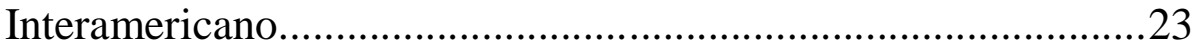

C) Alguns parâmetros da Corte Interamericana para justiça

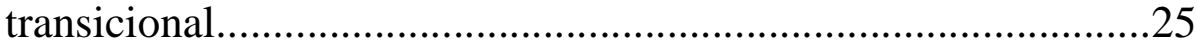

C.i) Direito à Verdade....................................................26

C.ii) Vedação de Leis de Auto-Anistia................................30

C.iii) Acesso à Informação...............................................33

Capítulo III - Desafios Apresentados pelo Caso Araguaia à Corte

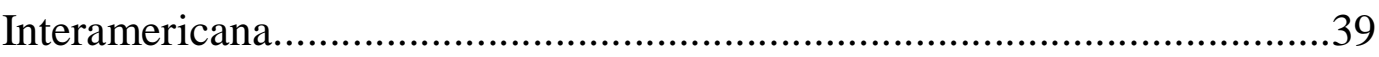

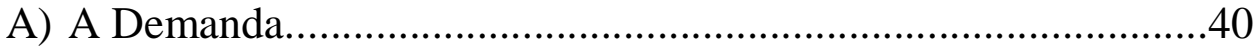

B) A Contextualização do Caso Araguaia....................................43

C) As violações da Convenção Americana Pertinentes ao Caso......45

C.i) Arts. $3^{\circ}, 4^{\circ}, 5^{\circ}$ e $7^{\circ}$ da Convenção Americana.................45

C.ii) Arts. $8^{\circ}$ e 25 c/c 1.1 e $2^{\circ}$ da Convenção Americana.......46

C.iii) Art. 13 c/c art. $2^{\circ}$ da Convenção Americana.................51

Conclusão. .55

Bibliografia. .59 


\section{LISTA DE ABREVIAÇÕES}

ADI - Ação Declaratória de Inconstitucionalidade

ADPF - Ação de Descumprimento de Preceito Fundamental

AI-5 - Ato Institucional no 5

Comissão - Comissão Interamericana de Direitos Humanos

Convenção/CADH - Convenção Americana sobre Direitos Humanos

Corte - Corte Interamericana de Direitos Humanos

OEA - Organização dos Estados Americanos

OAB - Ordem dos Advogados do Brasil

Pacto - Pacto de São José da Costa Rica

Relatoria Especial - Relatoria Especial sobre Liberdade de Expressão

Sistema/SIPDH - Sistema Interamericano de Proteção dos Direitos

Humanos

STF - Supremo Tribunal Federal

TPI - Tribunal Penal Internacional 


\section{INTRODUÇÃO}

A Lei de Anistia no Brasil, aprovada em 1979, permanece sendo até hoje um obstáculo ao ajuizamento de ações contra os perpretadores de violações aos direitos humanos cometidas durante o período de ditadura militar.

A história da segunda metade do século XX até os dias de hoje é uma história que pode ser contada por meio de guerras, insurgências, limpezas étnicas, ações repressivas autorizadas por Estados e impunidade institucionalizada dos perpretadores, sendo motivo sempre de muito sofrimento e tendo vitimado milhões de indivíduos em todo o mundo, na maioria deles civis. ${ }^{1}$

Em busca de dar respostas a tanta barbárie, a comunidade internacional e, em seguida, os próprios Estados, passaram a criar mecanismos de proteção, mecanismos estes que privilegiavam a justiça e a verdade por meio da responsabilização de indivíduos, como pela primeira vez ocorreu no Tribunal de Nuremberg após as atrocidades da Segunda Guerra Mundial. A demanda por estabelecer parâmetros de justiça para momentos de transição política repetiu-se em outros momentos da história, e assim se estabeleceu a denominada justiça transicional.

$\mathrm{Na}$ América Latina testemunhou-se esta realidade no período de Guerra Fria, quando vários países sofreram golpes militares, os quais em suas políticas utilizaram a tortura, desaparecimentos forçados e uma série de violações sistemáticas aos direitos fundamentais para permanecer no poder e reprimir manifestações, pacíficas ou não, contrárias aos regimes autoritários.

No momento em que os governos militares cederam, ficou caracterizada na América Latina uma leitura diferenciada dos mecanismos

\footnotetext{
${ }^{1}$ Daniel Rothenberg \& M. Cherif Bassiouni. The Chicago Principles on Post-Conflict Justice. (Chicago: The International Law Institute, 2007). p. 1.
} 
de justiça transicional da forma como vinham sendo tradicionalmente utilizados, partindo basicamente deste ponto o foco do presente trabalho.

O Brasil passou por todo esse processo de maneira intensa, sendo governado por militares de 1964 a 1985 . Com o retorno da democracia veio também a Lei de Anistia, a qual anistiou civis e militares pelos crimes cometidos durante o regime autoritário. Se por um lado a Lei de Anistia permitiu o retorno dos exilados políticos ao Brasil, foi também o que consagrou a impunidade dos militares e o encobrimento da verdade, mesmo que em contrariedade ao Direito Internacional dos Direitos Humanos.

Tal política foi compartilhada por muitos países que vivenciaram leis de anistia. No entanto, considerando as respostas dadas pelos demais países latino-americanos, a política de não revisão da lei de anistia pelo Estado brasileiro mostrou-se isolada, vez que todos os países que vivenciaram ditaduras militares estabeleceram comissões de verdade e/ou processaram os perpretadores de graves violações aos direitos fundamentais.

O presente trabalho se vale dos princípios instituídos pela justiça transicional e da jurisprudência desenvolvida pela Corte Interamericana de Direitos Humanos para abordar as questões relativas ao Caso Araguaia, o qual submeteu o Estado brasileiro ao julgamento da Corte por meio de uma demanda apresentada no ano de 2009 pela Comissão Interamericana de Direitos Humanos.

Não pretende-se fazer previsões acerca do julgamento, mas apenas buscar na jurisprudência da Corte Interamericana a forma como o Tribunal vem se posicionando acerca do direito à verdade, da adoção de leis de autoanistia e sobre o sigilo de documentos em poder do Estado. Nesse esforço, tentaremos demonstrar que há uma tendência internacional por estabelecer mecanismos de justiça transicional, os quais caminham no sentido de se proteger à verdade e a justiça, principalmente no que tange ao uso desses mecanismos na América Latina. Tal tendência é corroborada pela Corte Interamericana em julgamentos importantes sobre o tema e, em prol da manutenção e evolução desta proteção no Sistema Interamericano, o Caso 
Araguaia representa um novo desafio para a Corte na proteção desses direitos.

Sendo assim, são apresentados no primeiro capítulo alguns elementos que dizem respeito à justiça transicional, realizando um estudo da doutrina que discute o tema para demonstrar de que forma a América Latina incorporou e ainda desenvolveu mecanismos próprios de justiça transicional.

O capítulo seguinte realiza o estudo da evolução jurisprudencial da Corte Interamericana com relação ao direito à verdade, leis de auto-anistia e acesso à informação, buscando identificar nos principais precedentes da Corte, tais quais os Casos Bairros Altos, Almonacid Arellano, Bámaca Velásquez e a Opinião Consultiva $n^{\circ} 5$, parâmetros de proteção desses direitos dentro do Sistema Interamericano.

No terceiro capítulo é feita a leitura da demanda da Comissão Interamericana apresentada no Caso Araguaia, a qual é confrontada com os elementos de justiça transicional e com os parâmetros já estabelecidos pela Corte Interamericana para a proteção dos direitos supostamente violados. Desta forma, são demonstrados os principais desafios que o Caso Araguaia representa para a consolidação e possível evolução da jurisprudência da Corte, ao mesmo tempo em que o caso também é um desafio à postura adotada pelo Estado brasileiro que aparentemente não se adéqua aos parâmetros tradicionais estabelecidos pelo Tribunal.

Hoje a Corte Interamericana tem sob sua apreciação um caso capaz de fazer o Estado brasileiro abandonar, mesmo que tardiamente, uma postura de perpetuação da impunidade. Enfim há a real expectativa de ver o Estado atender ao que as vítimas têm demandado nas últimas três ou quatro décadas, revelando fatos e julgando os responsáveis pelos mais graves crimes cometidos contra a humanidade. Somente assim o Brasil poderá se juntar aos demais países da América do Sul na busca conjunta pela verdade. 


\section{Capítulo I - JUSTIÇA TRANSICIONAL NA AMÉRICA LATINA}

Com frequiência na história moderna vivemos situações em que o cenário político se transforma radicalmente, passando de uma política de abusos cometido contra a pessoa humana para uma nova política que supera e reflete acerca dos atos criminosos geralmente cometidos em nome do Estado. Nesse processo de mudança política fica caracterizada a necessidade de dar respostas legais aos abusos cometidos por regimes ou políticas repressivas precedentes, e a esta resposta se deu o nome de justiça transicional. $^{2}$

A justiça transicional pode ser observada em diversas ocasiões em que ocorre uma mudança onde a realidade política que sucede pretende repensar os atos anteriormente adotados como política de Estado. Não necessariamente deve haver uma transição de regimes, como, por exemplo, de um regime autoritário para um regime democrático. Mas uma mudança política quanto ao uso da tortura em investigações, usando como exemplo o caso dos Estados Unidos, já é suficiente para caracterizar um novo cenário político. A justiça transicional é também, portanto, uma alternativa para o pós-conflito interno. ${ }^{3}$

O termo justiça transicional pode ver-se substituído por termos ou conceitos similares, como: “justiça pós-conflito", “estratégias para combater a impunidade", "construção da paz" e "reconstrução pósconflito". Isso nos mostra a diversidade que compreende a natureza desse conceito, mostrando o quanto ele está relacionado a diversos institutos particulares e que na verdade não existe uma diferença substancial ou ideológica entre eles. ${ }^{4}$ Para entender a extensão e a duração deste processo de justiça transicional temos que ter em mente que a "justiça pós-conflito é mais bem compreendida como um processo definido por diversas ações que

\footnotetext{
${ }^{2}$ TEITEL, Ruti G. Transicional Justice Genealogy. Harvard Human Rights Journal 16. 2003. p. 69.

${ }^{3}$ Ibid. p. 71

${ }^{4}$ BASSIOUNI, M Cherif. The Chicago Principles on Post-Conflict Justice. (Chicago: The International Law Institute, 2007). p. 9.
} 
cumprem papéis determinados nas diferentes etapas da reconstrução e reconciliação nacional". 5

É possível imaginar então que existem inúmeras situações que podem levar à aplicação de uma justiça de transição, sendo razoável acreditar que a forma como o novo regime irá agir não deve coincidir com as políticas adotadas por outros países que passaram pela mesma situação. A resposta nos diferentes casos não será a mesma. Em alguns casos, por exemplo, observa-se a necessidade de perseguir e sancionar todos aqueles que participaram de determinado regime, o que não seria possível ou desejado em outros casos em que tenha havido alto grau de participação da sociedade no sistema político agora repugnado. ${ }^{6}$

É possível distinguir basicamente três fases no ciclo da justiça transicional na história moderna. O primeiro data do fim da Primeira Guerra Mundial, quando a justiça transicional era vista como um acontecimento extraordinário e internacional, tendo por referência o Tribunal de Nuremberg. A segunda fase é identificada pelo Pós-Guerra Fria, momento em que os países passam a utilizar a justiça transicional em meio a uma onda de transições democráticas e de modernização. A terceira fase, vivida atualmente, associa a justiça transicional ao conflito diário, constante, o qual normaliza a violência em nosso dia-a-dia. ${ }^{7}$ Destaca-se nesta terceira fase a associação do fenômeno da justiça transicional com a globalização, ou melhor, com a expansão e normalização da justiça transicional. O maior símbolo deste momento vivido pela justiça transicional é o Tribunal Penal Internacional, que marca o seu retorno à justiça internacional e incorpora a complexa relação entre o indivíduo e o Estado que permite à comunidade internacional processar líderes políticos e condenar políticas de perseguição. ${ }^{8}$

\footnotetext{
${ }^{5}$ Ibid. p. 24

${ }^{6}$ TINAJERO, Salvador. Verdad y Justicia. Derecho Internacional de los Derechos Humanos. México D. F.: Ediciones Coyoacán, S.A. de C.V., 2006. p 384.

${ }^{7}$ TEITEL, Ruti G.Op. Cit., p. 71.

${ }^{8}$ TEITEL, Ruti G.Op. Cit., p. 90.
} 
Características importantes conquistadas na segunda e da terceira fase que devem ser frisadas são, na segunda, a constituição de comissões de verdade como mecanismos ou meios para se alcançar a verdade e a justiça; e, na terceira fase, o ajuizamento de processos contra os responsáveis diretos pelas violações de direitos humanos, nos servindo como exemplo os Tribunais ad hoc para Ruanda e ex-Iugoslávia e a prisão do Gel. Augusto Pinochet em 1998.

$\mathrm{Na}$ realidade corrente, temos a aplicação regular da justiça transicional, abandonando o caráter extraordinário da primeira fase e se estabelecendo como um novo paradigma do devido processo legal para o direito internacional. ${ }^{9}$

A justiça transicional possui alguns pilares fundamentais. Ela compreende de maneira geral, segundo os princípios de Chicago para a justiça pós-conflito, alguns deveres ao Estado. São eles: o processamento dos alegados responsáveis por graves violações de direitos humanos; o respeito ao direito à verdade, sendo encorajada a investigação da verdade por meio de comissões de verdade ou outros órgãos; os Estados devem conferir status especial às vítimas, assegurando o acesso à Justiça e desenvolvendo remédios e formas de reparação; os Estados devem incentivar iniciativas oficiais e populares em memória das vítimas, devem educar a sociedade levando em consideração o passado de violência política e preservar a memória histórica; os Estados devem promover uma reforma institucional para favorecer o devido processo legal, restaurar a confiança pública, promover os direitos fundamentais e alcançar a boa governança. ${ }^{10}$

As premissas da justiça pós-conflito partem, portanto, do entendimento de que a estabilidade doméstica, segurança e governança no período subseqüiente ao conflito, são reforçadas pelo compromisso com a justiça e com a responsabilização. "Enfrentar abertamente o legado de

\footnotetext{
9 TEITEL, Ruiti. The law and politics of contemporary transitional justice," In Cornell International Law Journal 837, 2005, p. 840.

${ }^{10}$ BASSIOUNI, M Cherif . Op. Cit. Principle 7. p 17.
} 
violências do passado é essencial para prevenir a futura vitimização, alcançando a paz e a reconciliação e protegendo os direitos humanos". ${ }^{11}$

\section{a) Elementos de justiça transicional do continente}

O fim das ditaduras no final dos anos 80 na América Latina ficou caracterizado pela supressão de valores como a reparação das vítimas e a justiça em prol da construção da democracia, com a realização de eleições livres e a chamada reconciliação nacional. O temor à época girava em torno da possível fragilidade das novas democracias, que supostamente não poderiam resistir à pressão dos militares que acabavam de deixar o poder. ${ }^{12}$

Sob essa ameaça multiplicou-se a adoção de leis de anistia na América. Guatemala, El Salvador, Honduras, Nicarágua e Costa Rica firmaram o acordo de Esquipulas, um acordo internacional cujo elemento essencial era lograr a reconciliação nacional através da adoção de leis de anistia em cada país para todos os delitos políticos e conexos com os políticos. ${ }^{13} \mathrm{O}$ mesmo se deu na Argentina, no Chile, no Uruguai, no Brasil etc. Após esse processo, hoje, dos 16 países que passaram por leis de anistia, 15 vivenciaram processos judiciais contra os responsáveis pelas graves violações de direitos humanos. Apenas no Brasil a lei de anistia ainda impede o prosseguimento desses processos. ${ }^{14}$

Nesse contexto de impunidade relacionada às graves violações de direitos humanos cometidas em um passado recente, cresceu no continente a demanda pela verdade. Dessa forma, alguns países criaram comissões de verdade a fim de permitir que os fatos e autores de atos de violência fossem identificados, de maneira que todos saberiam a verdade histórica do que aconteceu durante os anos de ditadura militar.

\footnotetext{
${ }^{11}$ BASSIOUNI, M Cherif. Op. Cit. p. 2.

12 TINAJERO, Salvador. Op. Cit. p 385.

${ }^{13}$ Ibid. p 386.

14 SIKKINK, Kathryn; BOTH, Walling Carriel. The impact of human rights trials in Latin America, In: Journal of Peace Research Vol. 44, n. 04, 2007, p. 435.
} 
A criação de comissões de verdade é um marco na implementação de uma justiça transicional no continente, sendo um movimento que teve início nos países sul-americanos mas que atualmente a sua utilização já não se restringe aos países do Cone Sul. Sua utilização ficou caracterizada pela impossibilidade de se processar e julgar os agentes do Estado que violaram os direitos humanos, tornando-se as comissões uma alternativa para que houvesse, ao menos, o conhecimento da verdade. Exemplos deste movimento foram as criações da Comissão sobre o Desaparecimento de Pessoas (CONADEP) na Argentina em 1983 e da Comissão Nacional sobre Verdade e Reconciliação no Chile em $1990 .{ }^{15}$

Segundo os princípios da justiça transicional, os Estados podem aprovar leis de anistia ou adotar outros mecanismos que reduzam a responsabilidade por crimes passados desde que estes estejam de acordo com a legislação internacional. Para tanto, os Estados deveriam garantir que esses mecanismos não incentivam a impunidade e colaboram para a promoção dos objetivos da justiça transicional. Desta forma, políticas de anistia passam a ser mais aceitáveis quando protegem, por exemplo, os perpretadores de violência de mais baixa batente, crianças soldados, os responsáveis por crimes menos graves ou aqueles que foram forçados a cometer violações. ${ }^{16}$ Porém, essa não foi a características das leis de autoanistia aprovadas na América Latina.

Um dos princípios de Chicago sobre justiça pós-conflito, na verdade o primeiro princípio, diz que "os Estados devem processar os acusados de graves violações aos direitos humanos e à lei humanitária. Contudo, se o Estado é incapaz ou não demonstra interesse em instaurar processos sobre esses fatos, é possível que os casos sejam ajuizados em tribunais internacionais ${ }^{17}$.

\footnotetext{
${ }^{15}$ MELO, Carolina de Campos. Transitional Justice in South America: The Role of the InterAmerican Court of Human Rights. CEJIL. No 5. No prelo. p. 4.

${ }^{16}$ BASSIOUNI, M Cherif. Op. Cit. Principle $n^{\circ} 1.8$.

${ }^{17}$ Ibid. p. 30.
} 
A Corte Interamericana de Direitos Humanos, órgão vinculado à Organização dos Estados Americanos criado em 1969 no momento da adoção da Convenção Americana sobre Direitos Humanos, permaneceu distante deste processo até que chegassem a sua apreciação os Casos Bairros Altos e La Cantuta, ambos relativos à ditadura peruana, e Almonacid Arellano, contra o Chile. Nesse momento a Corte determinou, como veremos de forma mais detalhada no capítulo II, que, além de constituir comissões de verdade, o Estado dever tem o dever de permitir o andamento de ações judiciais contra os agentes acusados de violar os direitos humanos.

Com a instauração de casos na Corte, os indivíduos que tiveram seus direitos violados pediam mais do que a simples reparação pecuniária pelo o ocorrido durante os anos de ditadura, mas colocavam em xeque a validade das leis de auto-anistia, que impediam a instauração de processos em âmbito interno; desafiavam a conduta dos agentes do Estado que, mesmo sob um regime democrático, eram coniventes com a perpetuação da impunidade; e exigiam conhecer os fatos que os violentaram ou que levaram seus parentes de sua convivência, buscando identificar pessoas, elucidar um contexto e descobrir a verdade. Mais do que a reparação pecuniária que viria como parte do cumprimento da sentença, as vítimas desejavam um pedido de desculpas por parte do Estado através da justiça internacional e um amplo conhecimento de suas histórias na sociedade em que vivem.

Diante dessas necessidades, a Corte decidiu pela derrogação das leis de anistia daqueles países, as quais, segundo seu entendimento, violam os arts. $1.1,2^{\circ}, 8^{\circ}$ e 25 da Convenção Americana.

Nesse momento, a Corte declarava para todos os países membros da OEA que o juiz é responsável por realizar o controle de convencionalidade das leis internas do Estado. No caso chileno, quando a Corte determinou que os esforços envidados nos trabalhos da Comissão de Verdade e Reconciliação Nacional não eram suficientes para satisfazer as necessidades 
das vítimas, um amplo debate acerca do dever do juiz de não dar aplicabilidade a uma lei de auto-anistia em razão de obrigação assumida perante a comunidade internacional se iniciou. Tal postura reforça a atual tendência de observarmos um significante aumento na judicialização da política mundial $^{18}$.

Os Estados demonstravam-se ineficientes na tarefa de afastar a aplicabilidade das leis de auto-anistia, de forma que os processos contra os acusados por vários crimes, como no Caso peruano, demoravam anos para serem concluídos e, geralmente, essa conclusão era insatisfatória. A demora, ao contrário do que entoam os parâmetros da justiça transicional, nunca visava a proteção dos direitos das vítimas, os direitos dos alegados perpetradores ou a possibilidade de a celeridade no julgamento impactar a fidedignidade de algum testemunho ou prova. ${ }^{19} \mathrm{O}$ prolongamento dos processos no tempo demonstrou-se apenas como mais uma ferramenta para que se alcançasse a impunidade e a discricionariedade no momento da responsabilização de agentes do Estado, o que é veementemente contrário aos princípios da justiça pós-conflito.

\section{b) Superação de falsas dicotomias para momentos de transição}

Conforme demonstrado anteriormente, no segundo e no terceiro ciclos da justiça transicional há o estabelecimento das comissões de verdade e do ajuizamento de processos criminais para se levar adiante o processo de transição, porém até acreditava-se que este deveria ser um processo dicotômico e, por isso, era necessário escolher entre enfrentar o passado por meio de comissões de verdade ou por meio de processos judiciais.

No mesmo sentido em que se pronunciou a Corte nas sentenças sobre leis de auto-anistia no Sistema Interamericano, como será demonstrado no capítulo II deste trabalho, hoje os estudiosos da justiça transicional apontam

\footnotetext{
${ }^{18}$ SIKKINK, Kathryn; BOTH, Walling Carriel. Op. Cit., p. 430.

${ }^{19}$ BASSIOUNI, M Cherif. Op. Cit. p. 34. Principle ${ }^{\circ} 1.6$.
} 
o fim da dicotomia verdade vs. justiça em momentos de transição política, dizendo que paralelamente às atividades das comissões de verdade, o Estado tem o dever de dar prosseguimento a processos judiciais. ${ }^{20}$ De fato, todos os países da América que constituíram comissões de verdade também acabaram por aceitar a instauração de processos contra os que haviam sido supostamente anistiados, o que demonstra ser inexistente a oposição entre comissões de verdade e processos judiciais, ao contrário do que sugeriam alguns autores da literatura sobre justiça transicional. ${ }^{21}$

Esse fato demonstra também que alguns desses autores estavam enganados quando diziam que nunca se alcançaria a persecução criminal e sanção dos criminosos, sob o argumento de que a força desses atores (militares) se manteria constante, sem que as normas e atitudes da população em geral diante de seus atos fosse mudar. $\mathrm{O}$ advento dos princípios da justiça transicional mudou esse panorama na América Latina, tornando o ambiente cada vez mais propício para a instauração desses processos e reduzindo a influência desses atores, o que também certamente se deu em razão de uma profunda mudança no contexto regional e internacional por fatores diversos. ${ }^{22}$

Com essas mudanças foram sendo superadas tais dicotomias que, acreditava-se, deviam acompanhar as escolhas políticas que seriam feitas no momento de transição política. Uma delas se baseava na hipótese de que o emprego de processos contra militares ameaçaria a democracia que se pretendia construir (portanto, processos judiciais vs. democracia), o que poderia culminar em um novo golpe militar. Tal fato nunca se concretizou na América Latina, que saiu de uma realidade de instabilidade política e de golpes militares durante o séc. XX para se tornar uma região de democracias consolidadas. ${ }^{23}$ Não há, portanto, evidências de que a

\footnotetext{
${ }^{20}$ MELO, Carolina de Campos. Op. Cit.

${ }^{21}$ SIKKINK, Kathryn; BOTH, Walling Carriel. Op. Cit., p. 431.

${ }^{22}$ Ibid. p. 434.

${ }^{23}$ Ibid. p. 434.
} 
instauração desses processos tenha ameaçado regimes democráticos. Muito pelo contrário, eles parecem tê-los fortalecido.

Um exame dos mais graves crimes cometidos contra os direitos humanos na América Latina desde os tempos de ditadura até os dias atuais revela que não há coerência em privilegiar a democracia em prejuízo da instauração de processos judiciais se o objetivo é melhorar a proteção dos direitos humanos de forma geral. O Brasil, por exemplo, apesar de ter se consolidado como uma das democracias mais fortes do continente teve uma piora considerável na escala de proteção dos direitos humanos desde os "anos de chumbo" até hoje. Por outro lado, dos 14 países que apenas processaram os criminosos do passado na América Latina, 11 tiveram melhora nos níveis de proteção dos direitos humanos, excetuando-se apenas Haiti, México e Venezuela. ${ }^{24}$ Ademais, quando os países optaram por estabelecer processos judiciais e comissões de verdade sempre houve melhora na proteção dos direitos humanos.

Sem dúvida a transição para a democracia e a estabilidade desta colaboram muito para o desenvolvimento da proteção dos direitos humanos, mas deve-se manter em mente que isto também provém da responsabilização dos criminosos e de se descobrir o passado. Diante da realidade atual, portanto, não se pode afirmar com convicção que processar os responsáveis enseje uma ameaça à proteção dos direitos humanos se levarmos em conta a história recente da América Latina.

$\mathrm{Na}$ América Latina, 16 dos 19 países que passaram por situações de transição optaram por editar leis ou decretos-lei de auto-anistia. Desses 16, como já foi dito, 15 também tiveram a instauração de processos judiciais. Uma pesquisa desses processos sugere que nas regiões aonde eles vão se tornando comuns a passagem do tempo, ao invés de contribuir para o esquecimento da terrível realidade do passado, apenas encoraja as vítimas de outros países a trazerem à tona aqueles acontecimentos. ${ }^{25}$

\footnotetext{
${ }^{24}$ Ibid. p. 437.

${ }^{25}$ Ibid. p. 435.
} 
Isso mostra que a negociação no período pós-transição não é estável e nem dicotômica. ${ }^{26}$ Chile, Peru, Argentina, Guatemala etc. todos, por diferentes motivos, derrubaram suas leis de auto-anistia. Portanto, nada demonstra que as leis de auto-anistia foram efetivas em refrear abusos que antes eram mais freqüentes na região ou levaram ao esquecimento dos crimes cometidos pelo regime anterior. A única coisa que podemos concluir é que na América Latina as leis de auto-anistia não se mostraram suficientes para impedir a instauração de processos contra militares, ${ }^{27}$ salvo no caso brasileiro.

Um papel importante creditado à justiça transicional na América Latina se refere à consolidação do devido processo legal no sistema jurídico dos países que promoveram tais processos. ${ }^{28}$ Isso porque, quando consegue impor-se diante dos poderosos que comandaram a política nacional durante anos, o cidadão passa a compreender que o sistema jurídico é um meio viável e legítimo que pode ser usado na defesa de seus interesses. Quem conhece a realidade da América Latina, e do Brasil, pode compreender a importância de se estabelecer um sistema mais igualitário, no qual ninguém está acima da lei - o que é um dos ingredientes do devido processo legal. ${ }^{29}$

Muito se fez levando em conta o medo sobre o que aconteceria caso o interesse dos militares não fossem atendidos de alguma forma no momento da abertura democrática. A promulgação em massa de leis de anistia não revela outra coisa senão este medo sendo compartilhado em todo o continente. Há os que dizem que governos não democráticos não deixariam o poder se acreditassem que a anistia não seria respeitada no futuro. Não obstante a compreensibilidade deste receio, uma análise mais moderada revela que os governos ditatoriais não deixam o poder porque querem ou porque um dia seus governantes tornaram-se mais democráticos, mas porque passam a não ter outra alternativa senão a de abrir mão dele. ${ }^{30}$

\footnotetext{
${ }^{26}$ Ibid. p. 435.

${ }^{27}$ Ibid. p. 436.

${ }^{28}$ Ibid. p. 441.

${ }^{29}$ Ibid. p. 441.

${ }^{30}$ TINAJERO, Salvador. Op. Cit., p 402.
} 
Desta forma, naquele momento de a lei de anistia é só mais um elemento no palco de negociações, mas restou comprovado que ela está sujeita à reflexão com o decurso do tempo e a sua revisão se torna viável com a constante movimentação das peças que alteram jogo do poder.

Ao contrário do que acreditava-se nos primeiros anos pós-ditadura na América Latina, a escolha de ajuizar ações criminais contra os perpetradores das graves atentados contra o homem não é a única alternativa e nem mesmo só pode ocorrer imediatamente após uma transição política. Isso pode acontecer muitos anos após a transição ${ }^{31}$, como ocorreu no Uruguai, ou logo em seguida, como se deu na Argentina. ${ }^{32}$ Além disso, não há necessariamente que se escolher entre comissões de verdade e processos judiciais. A maioria dos países na América Latina optou por utilizar os dois mecanismos, e foi este o modelo mais bem sucedido quando avaliamos a evolução na proteção dos direitos humanos entre um período e outro. ${ }^{33}$

\footnotetext{
${ }^{31}$ SIKKINK, Kathryn; BOTH, Walling Carriel. Op. Cit., p. 442.

${ }^{32}$ TINAJERO, Salvador. Op. Cit., p 402

${ }^{33}$ SIKKINK, Kathryn; BOTH, Walling Carriel. Op. Cit., p. 442.
} 


\section{Capítulo II - O SISTEMA INTERAMERICANO DE PROTEÇÃO DOS DIREITOS HUMANOS:}

O Sistema Interamericano de Proteção dos Direitos Humanos desenvolveu-se na segunda metade do século XX, no contexto da Organização dos Estados Americanos. ${ }^{34} \mathrm{O}$ Sistema segue uma tendência de regionalização da tutela dos direitos humanos que também se estabeleceu na Europa, por meio do Sistema Europeu de Proteção dos Direitos Humanos e, ainda, na África, com o Sistema Africano.

\section{a) Órgãos de Proteção dos Direitos Humanos no Sistema}

A Convenção Americana de Direitos Humanos, aprovada em 1969, estabelece a existência e a competência da Comissão e da Corte Interamericanas como órgãos de proteção dos direitos previstos no Pacto de São José da Costa Rica.

A Comissão fora estabelecida em 1959, na Quinta Reunião de Consulta de Ministros de Relações Exteriores em Santiago do Chile; ao passo que a Corte Interamericana foi criada apenas em 1969, como órgão de supervisão judicial da vigência dos direitos previstos na Convenção Americana. A Corte, contudo, passou a funcionar apenas quando a Convenção entrou em vigor, 20 anos depois.

Os membros tanto da Comissão quanto da Corte devem ser pessoas de alta autoridade moral e reconhecido conhecimento em matéria de direitos humanos. Para a Corte, segundo o art. 52 do Pacto, o requisito adicional é que a pessoa seja um jurista que reúna as condições para desempenhar as mais altas funções judiciais.

A Comissão é um órgão que tutela os direitos por meio de atividades de promoção dos direitos humanos e também recebe casos individuais. $\mathrm{O}$

\footnotetext{
${ }^{34}$ Organização internacional criada pelos Estados americanos, mediante aprovação da Carta da OEA no início de 1948, em Bogotá; esta Carta foi modificada pelo Protocolo de Buenos Aires, de 1967, e pelo Protocolo de Cartagena das Índias.
} 
órgão atua dentro dos parâmetros estabelecidos pela Carta da OEA e da Convenção Americana, fiscalizando o respeito dos direitos humanos daqueles países que ratificaram a Convenção Americana e demais convenções também no âmbito interamericano de proteção dos direitos humanos. ${ }^{35}$

Dentre as atribuições da Comissão estão a capacidade de produzir relatórios a respeito de acontecimentos ou da realidade de determinado país com relação à proteção dos direitos humanos, a possibilidade de realizar visitas aos países e de emitir comunicados de imprensa. É possível também a tramitação de casos individuais na Comissão, para os quais ela tem o poder de emitir recomendações aos Estados. Quando tais recomendações são descumpridas, a Comissão pode ainda submeter o caso à jurisdição da Corte Interamericana. Não obstante tais atribuições, é conferida à Comissão a capacidade de adotar medidas cautelares ou de solicitar à Corte a adoção de medidas provisórias, podendo também celebrar audiências temáticas sobre as discussões relacionadas aos casos que nela tramitam.

Já a Corte tem a sua competência dividida em duas competências principais: a contenciosa e a consultiva.

Em sua competência contenciosa a Corte decide sobre casos e medidas provisórias. Os casos podem ser submetidos à sua jurisdição pelos Estados ou pela Comissão, apenas. O processamento de um caso perante a Comissão já serve como filtro para as atividades da Corte, visto que está disposto na Convenção Americana - e a própria Comissão normatizou a matéria em seu regulamento - alguns critérios para que esta envie ou não um caso para a Corte. Desta forma, há uma tentativa prévia à atividade da Corte de se analisar se foi ou não feita justiça no caso em particular. ${ }^{36}$

A Corte, em sua competência contenciosa, está facultada a conhecer qualquer caso relativo à aplicação e interpretação da Convenção, exercendo

\footnotetext{
${ }^{35}$ Ver artigos 18 a 20 do Estatuto da Comissão, 15, 23, 24, 25, 56 a 64 do Regulamento da Comissão, 41 e seguintes da Convenção Americana.

${ }^{36}$ Ver, artigo 44 do Regulamento da Comissão.
} 
jurisdição plena sobre todas as questões relacionadas os casos que lhe são submetidos. $^{37}$

No exercício de sua competência consultiva, por sua vez, a Corte emite as denominadas opiniões consultivas, pronunciando-se a respeito de um determinado assunto e também acerca da interpretação da própria Convenção Americana sobre Direitos Humanos ou dos demais tratados interamericanos que versam sobre o tema. A consulta pode ser solicitada por qualquer Estado Parte da OEA - não apenas os que ratificaram a Convenção - e pelos órgãos enumerados no capítulo X da Carta da OEA. ${ }^{38}$

\section{b) Obrigações Internacionais dos Estados no Sistema Interamericano}

Cumpre esclarecer, em primeiro lugar, que todos os países membros da Organização dos Estados Americanos estão obrigados a respeitar os direitos consagrados na Carta da OEA e na Declaração Americana dos Direitos e Deveres do Homem. Cabe adicionalmente aos Estados que ratificaram a Convenção Americana e os outros tratados internacionais celebrados no âmbito do Sistema Interamericano, o respeito desses especificamente.

Quando ratifica a Convenção Americana, o Estado Parte compromete-se em promover, proteger e sancionar as violações dos direitos e liberdades nela previstas. Os Estados obrigam-se a respeitar e garantir o pleno e livre exercício dos direitos fundamentais previstos na Convenção sem qualquer discriminação.

Ao ratificar o tratado os Estados comprometem-se de abster-se de condutas violatórias dos direitos garantidos na Convenção (como, por exemplo, não torturar), assim como realizar determinadas ações que permitam aos indivíduos o gozo daqueles direitos (como, por exemplo,

\footnotetext{
${ }^{37}$ CORTE IDH, Caso Velásquez Rodríguez. Exceções Preliminares. Sentença de 26 de julho de 1987. Serie C No. 1, párr. 29.

${ }^{38}$ Ver, artigo 64 da Convenção Americana.
} 
promover um sistema de administração da justiça ou garantir a defesa pública). ${ }^{39} \mathrm{O}$ Estado deve organizar-se e estruturar-se para assegurar o livre e pleno exercício dos direitos humanos. ${ }^{40}$

Nesta função o Estado pode, por ação ou omissão de seus órgãos ou da postura de seus representantes, ser responsabilizado internacionalmente, ainda que a atuação dos agentes estatais esteja fora do marco de suas funções ou sem autorização expressa do Estado.

Em razão da proteção judicial e do devido processo legal, o Estado deve prevenir, investigar e sancionar toda violação de direitos previstos na Convenção Americana, restabelecendo o direito violado quando possível e reparando os danos sofridos em razão da violação. ${ }^{41}$

A Corte Interamericana estabeleceu que a investigação levada a efeito pelo Estado deve ser feita diligentemente e não devem existir obstáculos formais que possam impedir sanções às graves violações aos direitos humanos. Esse é o caso, por exemplo, de anistia, prescrição de delitos ou excludentes de responsabilidades que pretendam impedir a investigação ou sanção desses crimes. ${ }^{42}$ Segundo a Corte Interamericana, o sistema de justiça deve estar organizado de forma a assegurar o cumprimento das obrigações internacionais.

$\mathrm{O}$ art. $2^{\circ}$ da Convenção Americana de Direitos Humanos determina que o Estado tem o dever de adotar uma legislação compatível com o tratado americano, a fim de tornar efetivas as suas disposições em âmbito interno.

A Corte vem sinalizando reiteradamente que toda violação de uma obrigação internacional que tenha produzido dano comporta o dever de repará-lo adequadamente, isso está disposto no art. 63.3 da Convenção Americana. Trata-se de uma norma de direito consuetudinário que constitui

\footnotetext{
${ }^{39}$ CEJIL, Centro pela Justiça e pelo Direito Internacional. A proteção da liberdade de expressão e o Sistema Interamericano. CEJIL. - San José, Costa Rica: Centro por La Justicia y El Derecho Internacional, 2005. p 31.

${ }^{40}$ CORTE IDH, Caso Velásquez Rodríguez. Op. Cit, párr. 166.

${ }^{41}$ Ibid. Párr. 166.

${ }^{42}$ Convenção Americana para Prevenir e Sancionar a Tortura,artigo 6.
} 
um dos princípios fundamentais do Direito Internacional dos Direitos Humanos sobre a responsabilidade internacional dos Estados. ${ }^{43}$

Tal reparação do dano requer, sempre que possível, uma reparação integral (restitutio in integrum) da pessoa que sofreu o dano. Isso envolve a compensação pelo dano ocorrido, exige que se investiguem os fatos que ocasionaram a violação e ainda que se determinem medidas que assegurem a não repetição do ato violatório.

A reparação da vítima enseja o restabelecimento da situação anterior à violação. Contudo, isso nem sempre é possível, ainda assim deverão ser estabelecidas medidas de não repetição, se determinará a investigação dos fatos, serão reparadas as consequências produzidas pela violação do direito e haverá o pagamento de uma indenização como forma de compensação pelos danos causados. A reparação será determinada na sentença proferida pela Corte e não poderá de forma alguma ser modificada ou descumprida pelo Estado obrigado, mesmo que invocando disposições de seu direito interno para tanto. $^{44}$

\section{c) Alguns Parâmetros da Corte Interamericana para justiça transicional}

A Convenção Americana estabelece que a liberdade de expressão compreende não apenas a liberdade do indivíduo de expressar o seu próprio pensamento, mas também a liberdade de "procurar, receber e difundir informações ou ideias de toda índole...”. A proteção contida no art. 13 não determina apenas o direito de alguém expressar-se livremente, mas também a ideia de que o indivíduo deve ter amplo acesso à informação.

Para a proteção deste direito no Sistema Interamericano, foi criada uma Relatoria específica, sendo esta a única Relatoria de funcionamento permanente no Sistema. Além do direito à liberdade de expressão, veremos

\footnotetext{
${ }^{43}$ CORTE IDH. Caso do Massacre de Mapiripán. Sentença 15 de setembro de 2005 . Párr. 243.

${ }^{44}$ Ibid. Párr. 244.
} 
mais adiante que o direito à memória e verdade também pode estar compreendido no bojo do art. 13 do Pacto.

Vejamos o art. 13 da Convenção em seu inteiro teor:

\section{Artículo 13. Libertad de Pensamiento y de Expresión}

1. Toda persona tiene derecho a la libertad de pensamiento y de expresión. Este derecho comprende la libertad de buscar, recibir y difundir informaciones e ideas de toda índole, sin consideración de fronteras, ya sea oralmente, por escrito o en forma impresa o artística, o por cualquier otro procedimiento de su elección.

2. El ejercicio del derecho previsto en el inciso precedente no puede estar sujeto a previa censura sino a responsabilidades ulteriores, las que deben estar expresamente fijadas por la ley y ser necesarias para asegurar:

a) el respeto a los derechos o a la reputación de los demás, o

b) la protección de la seguridad nacional, el orden público o la salud o la moral públicas.

3. No se puede restringir el derecho de expresión por vías o medios indirectos, tales como el abuso de controles oficiales o particulares de papel para periódicos, de frecuencias radioeléctricas, o de enseres y aparatos usados en la difusión de información o por cualesquiera otros medios encaminados a impedir la comunicación y la circulación de ideas y opiniones.

4. Los espectáculos públicos pueden ser sometidos por la ley a censura previa con el exclusivo objeto de regular el acceso a ellos para la protección moral de la infancia y la adolescencia, sin perjuicio de lo establecido en el inciso 2.

5. Estará prohibida por la ley toda propaganda en favor de la guerra y toda apología del odio nacional, racial o religioso que constituyan incitaciones a la violencia o cualquier otra acción ilegal similar contra cualquier persona o grupo de personas, por ningún motivo, inclusive los de raza, color, religión, idioma u origen nacional.

\section{c.i) Direito à Verdade.}

Não existe disposição expressa na Convenção Americana acerca do direito à verdade. Contudo, a Corte Interamericana sempre dispensou atenção especial à proteção da investigação de fatos violatórios dos direitos humanos, determinando sempre a busca pelos fatos submetidos à sua jurisdição como forma de reparação às vítimas e aos seus familiares. Tal imposição sempre se fez valer através da obrigação dos Estados Partes em oferecer garantias e proteção judiciais aos indivíduos, com fundamento no disposto nos arts. $8^{\circ}$ e 25 da Convenção. 
Apesar dessa omissão convencional acerca do direito à verdade, há no Sistema Interamericano uma tendência em declarar esse direito como um direito fundamental, o que se percebe através das interpretações que a Corte tem feito a respeito dos arts. $8^{\circ}$ e 25 , que prescrevem a importância de se investigar, identificar e punir responsáveis pelas graves violações e de levar até as vítimas o conhecimento dos fatos criminosos.

Na sentença do Caso Bámaca Velásquez, o primeiro em que a Corte trabalha a questão do direito à verdade, afirma-se que este direito está subsumido apenas na proteção dos artigos $8^{\circ}$ e 25 :

En el presente caso, es incuestionable que se impidió a las víctimas sobrevivientes, sus familiares y a los familiares de las víctimas que fallecieron, conocer la verdad acerca de los hechos ocurridos en Barrios Altos. ${ }^{45}$

Pese a lo anterior, en las circunstancias del presente caso, el derecho a la verdad se encuentra subsumido en el derecho de la víctima o sus familiares a obtener de los órganos competentes del Estado el esclarecimiento de los hechos violatorios y las responsabilidades correspondientes, a través de la investigación y el juzgamiento que previenen los artículos 8 y 25 de la Convención ${ }^{46}$

Por lo tanto, esta cuestión ha quedado resuelta al haberse señalado (supra párr. 39) que el Perú incurrió en la violación de los artículos 8 y 25 de la Convención, en relación con las garantías judiciales y la protección judicial. ${ }^{47}$

Em arrazoado na sentença do mesmo caso, o juiz Antonio Augusto Cançado Trindade faz ainda algumas observações inovadoras para o SIPDH acerca do direito à verdade.

Tiene, en mi entender, una dimensión más amplia de la que se pueda prima facie desprender del artículo 19 de la Declaración Universal de los Derechos Humanos de 1948. Más allá del enunciado en aquella disposición, que inspiró otras disposiciones congéneres de distintos tratados de derechos humanos, el derecho a la verdad, en última instancia, se impone también en señal de respeto a los muertos y a los vivos. El ocultamiento de los restos mortales de una persona desaparecida, en una flagrante falta de respeto a los mismos, amenaza romper el

\footnotetext{
${ }^{45}$ CORTE IDH, Caso Barrios Altos vs. Peru. Sentença de 14 de março de 2001 (fundamentação) Párr. 47.

${ }^{46}$ CORTE IDH, Caso Barrios Altos vs. Peru. Op. Cit. Párr. 48 e Caso Bámaca Velásquez vs. Guatemala. Sentença de 25 de novembro de 2000. Párr. 201.

${ }^{47}$ Corte IDH, Caso Barrios Altos vs. Peru. Op. Cit. Párr. 47, 48 e 49.
} 
lazo espiritual que vincula los muertos a los vivos, y atenta contra la solidaridad que debe guiar los rumbos del género humano en su dimensión temporal. ${ }^{48}$

Cumpre dizer ainda que na sentença deste caso, o Juiz Sérgio García Ramírez aduz em seu Voto Concorrente que, na forma como a Corte vinha impondo a obrigatoriedade de se fornecer às vítimas a verdade dos fatos por meio da investigação e ajuizamento dos responsáveis, o direito à verdade já estava sendo protegido também na sua dimensão social, e não apenas na individual. Ao final do seu voto, o juiz destacou a importância de se desenvolver o tema para que se fortaleça o papel da Corte Interamericana na proteção dos direitos humanos e no combate à impunidade: ${ }^{49}$

Esta es la primera vez que la Corte se refiere explícitamente al derecho a la verdad, aducido en la demanda de la Comisión. La novedad que la Sentencia aporta en este punto pudiera conducir a mayor exploración en el porvenir, que contribuya a fortalecer el papel de la jurisprudencia interamericana sobre derechos humanos como factor de lucha contra la impunidad. La demanda social de conocimiento de los hechos violatorios y el derecho individual al conocimiento de la verdad se dirigen claramente al destierro de la impunidad, que propicia la violación de los derechos humanos. ${ }^{50}$

Portanto, como destacou o juiz em seu voto, ainda há uma ampla margem para que a Corte desenvolva a sua jurisprudência acerca do direito à verdade, desenvolvimento este que vem sendo cobrado por peticionários e pela Comissão, que desejam estabelecer uma jurisprudência que melhor vincule o descobrimento dos fatos e circunstâncias de uma violação principalmente quando há a prática sistemática de desaparecimentos forçados - ao contexto de perpetuação da impunidade e de negação ao acesso à informação individual e coletiva.

Neste sentido, a Comissão Interamericana e os peticionários de maneira geral, tem se esforçado para vincular o direito à verdade também ao art. 13 da Convenção, tendo em vista que a liberdade de expressão protegida nesse artigo está intimamente ligada ao conhecimento de fatos

\footnotetext{
${ }^{48}$ Corte IDH, Caso Bámaca Velásquez vs. Guatemala. Op. Cit. Párr. 31.

${ }^{49}$ Ibid. Párr. 19.

${ }^{50}$ Ibid. Párr. 22.
} 
que sejam simultaneamente relevantes nas duas dimensões que vimos anteriormente, isto é, a individual e a coletiva.

A proteção do direito da coletividade à verdade segue a argumentação estabelecida para o direito previsto no art. 13, alegando que o direito à verdade é também fundamental em uma sociedade democrática. No entanto, quando violado em casos individuais, estaria caracterizada também a sua dimensão individual, visto que os familiares das vítimas tem o direito de conhecer os fatos, identificar os responsáveis pelas violações e saber o que aconteceu com seus familiares.

En sus alegatos finales, la Comisión aseguró que, como consecuencia de la desaparición de Bámaca Velásquez, el Estado violó el derecho a la verdad de los familiares de la víctima y de la sociedad en su conjunto. Al respecto, la Comisión afirmó que el derecho a la verdad tiene un carácter colectivo, que conlleva el derecho de la sociedad a "tener acceso a información esencial para el desarrollo de los sistemas democráticos", y un carácter particular, como derecho de los familiares de las víctimas a conocer lo sucedido con su ser querido, lo que permite una forma de reparación. La Corte Interamericana ha establecido el deber del Estado de investigar los hechos mientras se mantenga la incertidumbre sobre la suerte de la persona desaparecida, y la necesidad de brindar un recurso sencillo y rápido para el caso, con las debidas garantías. Siguiendo esta interpretación, la Comisión afirmó que este es un derecho que tiene la sociedad y que surge como principio emergente del derecho internacional bajo la interpretación dinámica de los tratados de derechos humanos y, en específico, de los artículos 1.1, 8, 25 y 13 de la Convención Americana. ${ }^{51}$

Este posicionamento foi reiterado pela Comissão nos Casos Bairros Altos vs. Peru e Almonacid Arellano vs. Chile, ambos os casos sobre promulgação de leis de auto-anistia, quando afirmava que a garantia das informações era indispensável para garantir a transparência da gestão estatal e para a proteção dos direitos humanos:

La Comisión alegó que el derecho a la verdad se fundamenta en los artículos 8 y 25 de la Convención, en la medida que ambos son "instrumentales" en el establecimiento judicial de los hechos y circunstancias que rodearon la violación de un derecho fundamental. Asimismo, señaló que este derecho se enraíza en el artículo 13.1 de la Convención, en cuanto reconoce el derecho a buscar y recibir información. Agregó que, en virtud de este artículo, sobre el Estado recae una obligación positiva de garantizar información esencial para preservar los derechos

\footnotetext{
${ }^{51}$ Ibid. Párr. 197.
} 
de las víctimas, asegurar la transparencia de la gestión estatal y la protección de los derechos humanos. ${ }^{52}$

No entanto, cumpre salientar que em todos esses casos a Corte entendeu que a obrigação do Estado em elucidar os fatos e circunstâncias envolvidas na violação de um direito fundamental estava contida na proteção dos arts $8^{\circ}$ e 25 , como vimos anteriormente.

\section{c.ii) Vedação de Leis de Auto-Anistia.}

A Corte Interamericana tem estabelecido parâmetros bastante uniformes e sólidos com relação convencionalidade das leis de anistia (ou leis de auto-anistia). A Corte marcou seu entendimento a respeito dessas leis através do julgamento de casos paradigmáticos, que são os Casos Bairros Altos e La Cantuta, ambos envolvendo o Peru, e Almonacid Arellano vs. Chile. Esses casos estabeleceram a necessidade de se adequar as legislações internas aos direitos previstos na Convenção, decidindo que os Estados não podiam se valer das leis de auto-anistia para criar obstáculos processuais à responsabilização dos criminosos. A inadmissibilidade das leis de auto-anistia foi declarada nos seguintes termos:

Esta Corte considera que son inadmisibles las disposiciones de amnistía, las disposiciones de prescripción y el establecimiento de excluyentes de responsabilidad que pretendan impedir la investigación y sanción de los responsables de las violaciones graves de los derechos humanos tales como la tortura, las ejecuciones sumarias, extralegales o arbitrarias y las desapariciones forzadas, todas ellas prohibidas por contravenir derechos inderogables reconocidos por el Derecho Internacional de los Derechos Humanos. ${ }^{53}$

Ficou entendido que as leis de auto-anistia tinham como finalidade principal impedir o prosseguimento de ações em âmbito interno que pudessem incriminar os agentes do Estado que tivessem adotado uma postura criminosa durante o regime político anterior. Dessa forma, como a

\footnotetext{
${ }^{52}$ CORTE IDH, Caso Barrios Altos vs. Peru. Op. Cit. Párr. 45.

${ }^{53}$ Ibid. Párr. 41.
} 
existência de leis de auto-anistia faz com que não se levem a cabo de forma eficaz os processos judiciais contra os acusados, decidiu a Corte que a promulgação e aplicação de leis de anistia em âmbito interno viola as obrigações gerais de respeito à Convenção previstas nos seus arts. 1.1 e $2^{\circ}$, conforme sentenciou no Caso Bairros Altos:

La Corte, conforme a lo alegado por la Comisión y no controvertido por el Estado, considera que las leyes de amnistía adoptadas por el Perú impidieron que los familiares de las víctimas y las víctimas sobrevivientes en el presente caso fueran oídas por un juez, conforme a lo señalado en el artículo 8.1 de la Convención; violaron el derecho a la protección judicial consagrado en el artículo 25 de la Convención; impidieron la investigación, persecución, captura, enjuiciamiento y sanción de los responsables de los hechos ocurridos en Barrios Altos, incumpliendo el artículo 1.1 de la Convención, y obstruyeron el esclarecimiento de los hechos del caso. Finalmente, la adopción de las leyes de autoamnistía incompatibles con la Convención incumplió la obligación de adecuar el derecho interno consagrada en el artículo 2 de la misma. ${ }^{54}$

Como não se permitia às vítimas nenhuma forma de proteção ou garantia judicial frente às atrocidades cometidas durante o período de ditadura militar, ficando essas sem direito de ação frente ao óbice das leis de anistia, a Corte entendeu que o advento de uma lei de auto-anistia viola também os arts. $8^{\circ}$ e 25 da Convenção Americana:

La Corte estima necesario enfatizar que, a la luz de las obligaciones generales consagradas en los artículos 1.1 y 2 de la Convención Americana, los Estados Partes tienen el deber de tomar las providencias de toda índole para que nadie sea sustraído de la protección judicial y del ejercicio del derecho a un recurso sencillo y eficaz, en los términos de los artículos 8 y 25 de la Convención. Es por ello que los Estados Partes en la Convención que adopten leyes que tengan este efecto, como lo son las leyes de autoamnistía, incurren en una violación de los artículos 8 y 25 en concordancia con los artículos 1.1 y 2 de la Convención. Las leyes de autoamnistía conducen a la indefensión de las víctimas y a la perpetuación de la impunidad, por lo que son manifiestamente incompatibles con la letra y el espíritu de la Convención Americana. Este tipo de leyes impide la identificación de los individuos responsables de violaciones a derechos humanos, ya que se obstaculiza la investigación y el acceso a la justicia e impide a las víctimas y a sus familiares conocer la verdad y recibir la reparación correspondiente. ${ }^{55}$

\footnotetext{
${ }^{54}$ Ibid. Párr. 42.

55 Ibid. Párr. 43.
} 
Como afirma o Juiz Antonio Augusto Cançado Trindade acerca da existência de leis de auto-anistia em âmbito interno, frente ao Direito Internacional dos Direitos Humanos essas leis só podem ser compreendidas como um mecanismo utilizado por governos de fato para alcançar à impunidade e encobrir a verdade. Dessa forma, não lhe deve ser atribuída validade tanto no plano internacional como em âmbito interno. Foi como o juiz se posicionou em voto concorrente no Caso Bairros Altos:

\begin{abstract}
Esta misma Corte observó, en una Opinión Consultiva de 1986, que la palabra "leyes" en los términos del artículo 30 de la Convención Americana significa norma jurídica de carácter general, ceñida al bien común, elaborada según el procedimiento constitucionalmente establecido, por órganos legislativos constitucionalmente previstos y democráticamente elegidos. ¿Quién se atrevería a insinuar que una "ley" de autoamnistía satisface a todos estos requisitos? No veo cómo negar que "leyes" de este tipo carecen de carácter general, por cuanto son medidas de excepción. Y ciertamente en nada contribuyen al bien común, sino todo lo contrario: configúranse como meros subterfugios para encubrir violaciones graves de los derechos humanos, impedir el conocimiento de la verdad (por más penosa que sea ésta) y obstaculizar el propio acceso a la justicia por parte de los victimados. En suma, no satisfacen los requisitos de "leyes" en el ámbito del Derecho Internacional de los Derechos Humanos. ${ }^{56}$
\end{abstract}

Em seguida, no mesmo caso, o juiz dá especial atenção aos valores supremos de verdade e justiça, os quais devem prevalecer sobre a normativa de direito interno que tente menoscabar a proteção desses direitos, o que é o caso específico das leis de auto-anistia. Na verdade, o juiz descaracteriza a própria natureza legal desses documentos:

Hay que tener presente, en relación con las leyes de autoamnistía, que su legalidad en el plano del derecho interno, al conllevar a la impunidad y la injusticia, encuéntrase en flagrante incompatibilidad con la normativa de protección del Derecho Internacional de los Derechos Humanos, acarreando violaciones de jure de los derechos de la persona humana. El corpus juris del Derecho Internacional de los Derechos Humanos pone de relieve que no todo lo que es legal en el ordenamiento jurídico interno lo es en el ordenamiento jurídico internacional, y aún más cuando están en juego valores superiores (como la verdad y la justicia). En realidad, lo que se pasó a denominar leyes de amnistía, y particularmente la modalidad perversa de las llamadas leyes de autoamnistía, aunque se consideren leyes bajo un determinado ordenamiento jurídico interno, no lo son en el ámbito del Derecho Internacional de los Derechos Humanos. ${ }^{57}$

\footnotetext{
${ }^{56}$ Ibid. Párr. 7.

${ }^{57}$ Ibid. Voto Concorrente do Juiz A. A. Cançado Trindade. Párr. 6.
} 
No mesmo sentido dispôs a sentença do Tribunal Americano no Caso Bairros Altos. Naquela oportunidade ficou declarada a inaplicabilidade da lei de auto-anistia em âmbito interno, a qual carecia de efeitos jurídicos e não poderia representar um obstáculo para a devida investigação dos fatos ou para a identificação e castigo dos responsáveis. In verbis:

Como consecuencia de la manifiesta incompatibilidad entre las leyes de autoamnistía y la Convención Americana sobre Derechos Humanos, las mencionadas leyes carecen de efectos jurídicos y no pueden seguir representando un obstáculo para la investigación de los hechos que constituyen este caso ni para la identificación y el castigo de los responsables, ni puedan tener igual o similar impacto respecto de otros casos de violación de los derechos consagrados en la Convención Americana acontecidos en el Perú. ${ }^{58}$

Resta demonstrado que tal posicionamento vem sendo recorrentemente adotado nos casos submetidos à Corte que se relacionam à leis de auto-anistia promulgadas no Chile e no Peru. No capítulo III este trabalho abordará o próximo caso a ser analisado pela Corte sobre esta temática. O caso da Lei de Anistia brasileira torna a submeter à Corte os mesmos problemas, mas falando do contexto de ditadura militar neste país.

\section{c.iii) Acesso à informação}

De acordo com os pronunciamentos da Corte na Opinião Consultiva $\mathrm{n}^{\mathrm{o}} 5$, que trata da colegiatura obrigatória de jornalistas ${ }^{59}$ e o Caso A Última Tentação de Cristo vs. Chile ${ }^{60}$, ficou entendido que o direito garantido no art. 13 da Convenção devia ser protegido tanto em sua dimensão individual quanto na sua dimensão coletiva.

\footnotetext{
${ }^{58}$ Corte IDH, Caso Barrios Altos vs. Peru. Sentença de 14 de março de 2001 (fundamentação) Párr. 44.

${ }^{59}$ Corte IDH. Opinión Consultiva OC-5/85 del 13 de noviembre de 1985 (arts. 13 e 29 da Convenção Americana sobre Direitos Humanos).

${ }^{60}$ Corte IDH, Caso A Última Tentação de Cristo (Olmedo Bustos e outros). Sentença de 5 de fevereiro de 2001. Série C. No. 73. Párr. 64.
} 
Portanto, individualmente deve ser garantido o direito de falar ou escrever e o de se valer de qualquer meio apropriado para a difusão do pensamento, fazendo com que este alcance o maior número de pessoas possíveis ou desejadas.

Coletivamente, protege-se o direito à livre circulação de ideias e informações, tendo em vista que além da importância de difundir a informação, é essencial para o cidadão poder receber a informação alheia e poder realizar um intercâmbio de ideias. ${ }^{61}$ Nas palavras da Corte: "Neste sentido, a expressão e a difusão do pensamento e da informação são indivisíveis". ${ }^{62}$ Conforme segue:

Quando se restringe ilegalmente a liberdade de expressão de um indivíduo, não é só o direito do indivíduo que está sendo violado, mas também o direito de todos a "receber" informações e idéias... Põem-se assim manifesto as duas dimensões da liberdade de expressão. Em efeito, esta requer, por um lado, que ninguém seja arbitrariamente menoscabado ou impedido de manifestar seu próprio pensamento e representa, portanto, um direito de cada indivíduo; mas implica também, por outro lado, um direito coletivo a receber qualquer informação e a conhecer a expressão do pensamento alheio. ${ }^{63}$

Com relação à importância do direito previsto no art. 13 da $\mathrm{CADH}$, tendo em vista que a liberdade de expressão é fundamental para a livre circulação de ideias e informações entre as pessoas, a Corte se pronunciou no sentido de que:

[d]entro de uma sociedade democrática [é necessário que] sejam garantidas as maiores possibilidades de circulação de notícias, idéias e opiniões, assim como o mais amplo acesso à informação por parte da sociedade em seu conjunto... Tal como está concebido pela Convenção Americana, [é necessário] que seja respeitado escrupulosamente o direito de cada ser humano de se expressar livremente e o da sociedade em seu conjunto de receber informação ${ }^{64}$.

\footnotetext{
${ }^{61}$ Corte IDH, Caso A Última Tentação de Cristo (Olmedo Bustos e outros). Sentença de 5 de fevereiro de 2001. Série C. No. 73. Párr. 66.

62 Ibid. Párr. 65.

${ }^{63}$ Corte IDH. Opinión Consultiva OC-5/85 del 13 de noviembre de 1985 (arts. 13 e 29 Convención Americana sobre Derechos Humanos). Cit., párr. 30.

${ }^{64}$ Ibid. Párr.. 69.
} 
Contudo, na redação do art. 13 da Convenção existem limites ao exercício da liberdade de expressão. Por isso, em consonância com os itens 2, 3, 4 e 5 do art. 13 da Convenção Americana, a Corte Interamericana relativiza a proteção da liberdade de expressão, estabelecendo que este não é um direito absoluto. Apesar disso, quando se pronunciou a respeito da colegiatura obrigatória de jornalistas, a Corte determinou que tais limitações à liberdade de expressão deveriam levar em conta os critérios estabelecidos nos arts. 29 e 32.2 da Convenção, que tratam do princípio pro homine. $^{65}$

Dessa forma, a Corte estabeleceu que as restrições, além de serem aplicadas de forma a não censurar previamente qualquer informação, e sim fazendo-o por meio de responsabilização ulterior, devem levar em conta critérios de utilidade, razoabilidade, oportunidade e, por fim, o da proporcionalidade. Esse último critério exige que a medida adotada seja a "menos restritiv[a] possível para alcançar o interesse motivador do governo". ${ }^{66}$ É, portanto, indispensável que seja feita pelo agente do Estado uma ponderação entre a importância do objetivo coletivo da restrição (manutenção da ordem, por exemplo) e a necessidade social do pleno exercício da liberdade de expressão, de forma que não limite indevidamente o gozo desse direito fundamental. ${ }^{67}$

A Corte estabelece ainda outros parâmetros para a proteção da liberdade de expressão, tal qual a vedação à discriminação para o exercício desse direito e a proibição de restrições indiretas ao pleno exercício da liberdade de expressão, os quais não se pretende aprofundar o estudo neste trabalho. Também não parece necessário discorrer acerca dos critérios

\footnotetext{
${ }^{65}$ Ibid. Párr. 12. A Corte estabelece ese principio como um “...principio de interpretación extensiva de los derechos humanos y restrictiva de sus limitaciones (principio pro homine)..." ${ }^{66} \mathrm{CIDH}$, Relatório sobre Terrorismo e direitos Humanos, Cit. Párr. 278. Apud CEJIL, Centro pela Justiça e pelo Direito Internacional. A proteção da liberdade de expressão e o Sistema Interamericano. CEJIL. - San José, Costa Rica: Centro por La Justicia y El Derecho Internacional, 2005. p. 82

${ }^{67}$ Ibid. p. 91.
} 
estabelecidos pela Corte para que haja responsabilização ulterior ${ }^{68}$ daquele que fez mal uso da sua liberdade de expressão, por entender que estes critérios pouco acrescentariam para a solução do problema enfrentado neste trabalho.

Como foi possível constatar, está no bojo da liberdade de expressão o direito de todo cidadão de buscar informação, o que é imprescindível para a existência de um livre debate de ideias e para o desenvolvimento das sociedades democráticas.

Neste sentido, a Relatoria Especial de Liberdade de Expressão entendeu que o acesso à informação requer do Estado uma postura não apenas de abstenção, mas uma postura positiva de garantidor desse direito. Vejamos:

O controle efetivo dos cidadãos sobre as ações públicas requer não somente uma abstenção por parte do Estado de censurar informação, mas também requer a ação positiva de proporcionar informação aos cidadãos. É evidente que sem esta informação, a que todas as pessoas têm direito, não se pode exercer a liberdade de expressão como um mecanismo efetivo de participação cidadã nem de controle democrático da gestão governamental. ${ }^{69}$

Seguindo esse raciocínio, concluiu-se que "as pessoas têm o direito de requerer documentação e informação registrada em arquivos públicos ou processada pelo Estado, ou seja, informação considerada de uma fonte pública ou documentação oficial do Estado". 70 Além disso, estabeleceu a Comissão que a proteção do acesso à informação abriga o princípio da máxima divulgação, que equivale à presunção de que a informação será revelada pelo governo. ${ }^{71}$

\footnotetext{
${ }^{68}$ CORTE IDH, Caso Herrera Ulloa vs. Costa Rica. Sentença de 2 de julo de 2004. Párr 120: "Para poder determinar responsabilidades ulteriores es necesario que se cumplan tres requisitos, a saber: 1) deben estar expresamente fijadas por la ley; 2) deben estar destinadas a proteger ya sea los derechos o la reputación de los demás, o la protección de la seguridad nacional, el orden público o la salud o moral pública; y 3 ) deben ser necesarias en una sociedad democrática."

${ }^{69}$ CIDH, Relatório Anual da Relatoria Especial para a Liberdade de Expressão, 2001. Cit., Capítulo III, Párr. 16. Apud CEJIL, Centro pela Justiça e pelo Direito Internacional. A proteção da liberdade de expressão e o Sistema Interamericano. CEJIL. - San José, Costa Rica: Centro por La Justicia y El Derecho Internacional, 2005. p. 90

${ }^{70}$ Ibid. p. 90.

${ }^{71}$ Ibid. p. 91.
} 
Tudo isso se faz valer pela crença de que o livre acesso à informação em poder do Estado irá contribuir para a maior transparência dos atos do governo, o que influi diretamente na diminuição da corrupção estatal. Dessa forma, tanto a Relatoria Especial quando à Comissão se pronunciaram no sentido de que para a promoção do controle democrático da gestão governamental só se devem aceitar excepcionalmente as limitações ao acesso à informação.

Essas limitações estariam adstritas às limitações expostas no art. 13 da Convenção com relação à aplicação de sanções, isto é, ao controle ulterior por meio de responsabilização ou aos critérios de respeito aos direitos ou reputação de outrem; ou proteção da segurança nacional, ordem pública etc. Segue mais uma vez o que diz o art. 13.2 a fim de identificar na Convenção esses critérios:

2. O exercício do direito previsto no inciso precedente não pode estar sujeito a censura prévia, mas a responsabilidades ulteriores, que devem ser expressamente fixadas pela lei e que se façam necessárias para assegurar:

a) o respeito aos direitos ou à reputação das demais pessoas; ou

b) a proteção da segurança nacional, da ordem pública, ou da saúde ou da moral públicas. (grifos nossos)

Portanto, caberá ao Estado demonstrar a observância dos critérios acima identificados para justificar as restrições à liberdade de expressão que venha a impor aos seus cidadãos em caráter de censura prévia. A Relatoria Especial, inclusive, declarou que essa negação de acesso à informação deve ser avaliada caso a caso, sendo ainda necessário assegurar que tal negativa seja revista por uma instância judicial independente e que seja capaz de fazer o juízo de ponderação entre a segurança nacional e o interesse legítimo do cidadão de ter acesso aos documentos. ${ }^{72}$

Neste ponto, a Declaração de Princípios sobre Liberdade de Expressão é taxativa:

\footnotetext{
${ }^{72}$ CEJIL, Centro pela Justiça e pelo Direito Internacional. Op. Cit. p. 91.
} 
4. O acesso à informação em poder do Estado é um direito fundamental do indivíduo. Os Estados estão obrigados a garantir o exercício desse direito. Este princípio só admite limitações excepcionais que devem estar previamente estabelecidas em lei para o caso de existência de perigo real e iminente que ameace a segurança nacional em sociedades democráticas.

Desta forma, conclui-se que o acesso à informação, tal qual o direito à liberdade de expressão, apesar de ser reconhecidamente um direito fundamental, também não é tido como um direito absoluto, estando sujeito à limitações que seguem critérios previamente estabelecidos na Convenção.

Sem dúvida este é um assunto que traz muita polêmica, principalmente se levado em conta o contexto político no qual a Convenção Americana foi ratificada por muitos países da América Latina, quando os critérios de segurança nacional e manutenção da ordem publica eram de forma ampla e injustificada utilizados pelos regimes autoritários dos diferentes países que assinaram o tratado.

A utilização destes critérios exige, mais uma vez, fundamentação, a fim de não se impedir o livre acesso a documentos e, portanto, à informação - essencial para o livre debate em uma sociedade democrática. 


\section{Capítulo III - DESAFIOS APRESENTADOS PELO CASO}

\section{ARAGUAIA À CORTE INTERAMERICANA}

O caso Araguaia refere-se ao contexto de ditadura militar no Brasil, mais precisamente aos acontecimentos que envolveram a detenção arbitrária, tortura e desaparecimento forçado de 70 pessoas que estavam na região do Rio Araguaia nos anos de 1972 a 1975, quando membros do Partido Comunista do Brasil e moradores da região formaram o que veio a ser conhecida como a Guerrilha do Araguaia, que visava a combater o regime ditatorial então vigente no país. A Guerrilha foi alvo de operações promovidas pela Forças Armadas que visavam e conseguiram erradicá-la.

De acordo com as informações constantes da demanda em que a Comissão Interamericana enviou para Corte Interamericana, a Comissão Interamericana recebeu uma petição em face do Estado brasileiro em 7 de agosto de 1995, apresentada pelo Centro pela Justiça e Direito Internacional (CEJIL) e por Human Rights Watch/Americas, aos quais se uniram como co-peticionários o Grupo Tortura Nunca Mais do Rio de Janeiro, a Comissão de Familiares de Mortos e Desaparecidos Políticos do Instituto de Estudos da Violência do Estado e a senhora Ângela Harkavy.

Após o trâmite regular do processo na Comissão, este órgão concluiu em seu Relatório de Mérito nº 91/08, de 31 de outubro de 2008, o seguinte:

que o Estado brasileiro deteve arbitrariamente, torturou e desapareceu os membros do $\mathrm{PCdoB}$ e os camponeses listados no parágrafo 94 deste Relatório. Além disso, a CIDH conclui[u] que, em virtude da Lei 6.683/79 (Lei de Anistia), promulgada pelo governo militar do Brasil, o Estado não levou a cabo nenhuma investigação penal para julgar e sancionar os responsáveis por estes desaparecimentos forçados; que os recursos judiciais de natureza civil com vistas a obter informação sobre os fatos não foram efetivos para garantir aos familiares dos desaparecidos o acesso à informação sobre a Guerrilha do Araguaia; que as medidas legislativas e administrativas adotadas pelo Estado restringiram indevidamente o direito ao acesso à informação desses familiares; e que o desaparecimento forçado das vítimas, a impunidade dos seus responsáveis, e a falta de acesso à justiça, à verdade e à informação afetaram negativamente a integridade pessoal dos familiares dos desaparecidos. 
Sendo assim, neste Relatório de Mérito a Comissão fez uma série de recomendações ao Estado brasileiro a fim de fazer cessar as violações reconhecidas no Relatório, outorgar reparação às vítimas e implementar medidas de não-repetição. No entanto, após analisar as informações oferecidas pelo Estado para demonstrar o cumprimento das recomendações, a Comissão considerou insatisfatória a implementação destas e, em 25 de março de 2009, decidiu submeter o caso à Corte.

\section{a) A Demanda}

O Caso Julia Gomes Lund e outros vs. Brasil (Caso Araguaia) foi submetido à Corte em 26 de março de 2009. Segundo a Comissão, o Estado brasileiro deve ser considerado responsável internacionalmente por violações a direitos humanos pelos seguintes motivos: (i) a promulgação da Lei $N^{\circ}$ 6.683/79 ("Lei de Anistia”), que fez com que não se levassem a cabo as investigações penais com o objetivo de julgar e sancionar os responsáveis pelo desaparecimento forçado das 70 vítimas e pela execução extrajudicial de Maria Lucia Petit da Silva, cujos restos mortais foram encontrados e identificados em 14 de maio de 1996; (ii) os recursos judiciais de natureza civil com vistas a obter informação sobre os fatos não foram efetivos para garantir aos familiares dos desaparecidos e da pessoa executada o acesso à informação sobre a Guerrilha do Araguaia; (iii) as medidas legislativas e administrativas adotadas pelo Estado restringiram indevidamente o direito de acesso à informação dos familiares; (iv) e o desaparecimento das vítimas, a execução de Maria Lucia Petit da Silva, a impunidade dos responsáveis e a falta de acesso à justiça, à verdade e à informação, afetaram a integridade pessoal dos familiares dos desaparecidos e da pessoa executada. ${ }^{73}$

\footnotetext{
${ }^{73}$ CIDH, Caso Julia Gomes Lund e outros vs. Brasil. Demanda perante a Corte Interamericana de Direitos Humanos. 26 de março de 2009. Párr. 6.
} 
Diante do objeto da demanda acima, consideramos relevante destacar os pontos que abordam diretamente a questão da promulgação e aplicação da Lei de Anistia e a falta de acesso às informações sobre o que aconteceu com os membros da guerrilha. Esses são os pontos que nos parecem mais importantes para a nossa análise no caso em questão, tendo em vista a possibilidade que a Corte Interamericana tem de desenvolver sua jurisprudência acerca do direito à verdade e do acesso à informação, dando sequência à evolução jurisprudencial sobre o tema.

A própria Comissão destaca a importância de submeter tal caso à Corte e frisa a oportunidade de desenvolver-se uma jurisprudência nesse sentido na Corte Interamericana:

\begin{abstract}
A Comissão observa que o presente caso representa uma oportunidade importante para consolidar a jurisprudência interamericana sobre as leis de anistia em relação aos desaparecimentos forçados e a execução extrajudicial, e a resultante obrigação dos Estados de fazer a sociedade conhecer a verdade, e investigar, processar e sancionar as graves violações de direitos humanos. Além disso, a CIDH considera relevante ressaltar o valor histórico do presente caso, que é o único perante o Sistema Interamericano referente à ditadura militar do Brasil, e que possibilita à Corte afirmar a incompatibilidade da lei de anistia brasileira com a Convenção, no que se refere a graves violações de direitos humanos, assim como a incompatibilidade das leis de sigilo de documentos com a Convenção Americana, a fim de reparar as vítimas e promover a consolidação do estado democrático de direito no Brasil, garantindo o direito à verdade de toda a sociedade brasileira sobre fatos tão graves. ${ }^{74}$
\end{abstract}

Levando em consideração as violações em que incorreu o Estado brasileiro segundo o Relatório de Mérito 91/08, a Comissão pede na demanda do Caso Araguaia que o Estado seja, em relação à Convenção Americana sobre Direitos Humanos, responsabilizado internacionalmente nos seguintes termos:

a. violação dos direitos à personalidade jurídica, vida, integridade pessoal $\mathrm{e}$ liberdade pessoal (artigos 3, 4, 5 e 7), em conexão com o artigo 1.1, todos da Convenção Americana, com respeito às 70 vítimas desaparecidas;

b. violação dos direitos às garantias judiciais e à proteção judicial (artigos 8.1 e 25), em relação com os artigos 1.1 e 2, todos da Convenção, em detrimento das vítimas desaparecidas e seus familiares, assim como da

${ }^{74}$ Ibid. Párr. 5. 
pessoa executada e seus familiares, em virtude da aplicação da lei de anistia à investigação sobre os fatos;

c. violação dos direitos às garantias judiciais e à proteção judicial (artigos 8.1 e 25), em relação com o artigo 1.1, todos da Convenção, em detrimento das vítimas desaparecidas e seus familiares, assim como da pessoa executada e seus familiares, em virtude da ineficácia das ações judiciais não penais interpostas no marco do presente caso;

d. violação do direito à liberdade de pensamento e de expressão (artigo 13), em relação com o artigo 1.1, ambos da Convenção, em prejuízo dos familiares das vítimas desaparecidas e da pessoa executada, em função da falta de acesso à informação sobre o ocorrido; e

e. violação do direito à integridade pessoal (artigo 5), em conexão com o artigo 1.1, ambos da Convenção, em prejuízo dos familiares dos desaparecidos e da pessoa executada, em função do impacto negativo e sofrimento gerados pela impunidade dos responsáveis; assim como a falta de acesso à justiça, à verdade e à informação. ${ }^{75}$

E solicita que a Corte Interamericana, caso seja reconhecida a responsabilidade internacional do Brasil nos termos supracitados, ordene ao Estado:

a. Adotar todas as medidas que sejam necessárias, a fim de garantir que a Lei $\mathrm{N}^{\circ}$ 6.683/79 (Lei de Anistia) não continue representando um obstáculo para a persecução penal de graves violações de direitos humanos que constituam crimes contra a humanidade;

b. Determinar, através da jurisdição de direito comum, a responsabilidade penal pelos desaparecimentos forçados das vítimas da Guerrilha do Araguaia, e a execução de Maria Lucia Petit da Silva, mediante uma investigação judicial completa e imparcial dos fatos com observância ao devido processo legal, a fim de identificar os responsáveis por tais violações e sancioná-los penalmente; e publicar os resultados dessa investigação. Em cumprimento desta recomendação, o Estado deverá levar em conta que tais crimes contra a humanidade são insuscetíveis de anistia e imprescritíveis;

c. Realizar todas as ações e modificações legais necessárias a fim de sistematizar e publicar todos os documentos relacionados com as operações militares contra a Guerrilha do Araguaia;

d. Fortalecer, com recursos financeiros e logísticos, os esforços já empreendidos na busca e sepultura das vítimas desaparecidas cujos restos mortais ainda não hajam sido encontrados e/ou identificados;

e. Outorgar uma reparação aos familiares das vítimas desaparecidas e da pessoa executada, que inclua o tratamento físico e psicológico, assim como a celebração de atos de importância simbólica que garantam a não

${ }^{75}$ Ibid. Párr. 7. 
repetição dos delitos cometidos no presente caso e o reconhecimento da responsabilidade do Estado pelo desaparecimento das vítimas e o sofrimento de seus familiares;

f. Implementar, dentro de um prazo razoável, programas de educação em direitos humanos permanentes dentro das Forças Armadas brasileiras, em todos os níveis hierárquicos, e incluir especial menção no currículo de tais programas de treinamento ao presente caso e aos instrumentos internacionais de direitos humanos, especificamente os relacionados com o desaparecimento forçado de pessoas e a tortura; e

g. Tipificar no seu ordenamento interno o crime de desaparecimento forçado, conforme os elementos constitutivos do mesmo estabelecidos nos instrumentos internacionais respectivos.

A Comissão deixa muito claro em sua demanda a dificuldade em se determinar os fatos relacionados às operações promovidas pelo exército brasileiro contra a Guerrilha do Araguaia. Devido às dificuldades de se superar os obstáculos para obter informações das Forças Armadas, ela reconhece que pode haver possíveis contradições ou imprecisões na demanda com relação aos fatos nela apontados.

\section{b) A Contextualização do Caso Araguaia}

O governo militar no Brasil teve início em 1964 quando os militares derrubaram o Presidente João Goulart, tendo perdurado até o ano de 1985. Em 1968 o governo militar aprovou o Ato Institucional $n^{\circ} 5$, ato que ficou conhecido como o "golpe dentro do golpe". Com o AI-5 outorgou-se ao Presidente da República poderes legislativos ilimitados, foram suprimidas garantias fundamentais como direito ao habeas corpus e foi negado o direito a uma revisão judicial de condutas previstas no texto do Ato Institucional a fim de preservar a ordem ou a segurança nacional. ${ }^{76}$

Durante os 21 anos de regime militar foram observados momentos de maior ou menor repressão e violência do Estado, o que se convencionou chamar de "aberturas" e "endurecimentos". No período entre 1968 a 1974 foram realizadas grande parte das operações militares que resultaram no

\footnotetext{
${ }^{76}$ MELO, Carolina de Campos. Op. Cit. No prelo.
} 
desaparecimento forçado de pessoas que faziam parte da resistência ao regime.

Com o advento do AI-5 em 1968 o aparelho repressivo da ditadura militar "assumiu características de verdadeiro poder paralelo ao Estado"77, servindo como manto protetor para os atos de violência que os militares cometiam em nome do regime. Um ano mais tarde a pena de morte e a prisão perpétua para opositores que estivessem envolvidos em ações armadas que tivessem causado morte também estariam sendo instituídas no país.

Nesse clima de "terror de Estado" o regime adentra na década de 70, dedicando-se a suprimir a qualquer custo todas as grandes organizações contrárias ao poder militar. Foi assim que entre 1972 e 1974 o regime combateu e exterminou a base guerrilheira que o Partido Comunista do Brasil (PCdoB) mantinha na região do Araguaia. ${ }^{78}$

O regime de atentados a bomba, depredação de jornais e revistas, tortura e assassinatos seguiu até que, no final da década, em 1979, foi adotada a Lei de Anistia, a qual incorpora o conceito de crimes conexos para beneficiar, em tese, os agentes do Estado. A Lei também permite à época o retorno ao Brasil de lideranças políticas que estavam no exílio. ${ }^{79}$

Em 1988, finalmente, é promulgada em 5 de outubro a Constituição Federal, declarando o país como uma democracia representativa e participativa, permitindo de fato a existência de uma pluralidade de novas siglas partidárias e consolidando o princípio da dignidade da pessoa humana no texto constitucional. ${ }^{80}$

Mais tarde, em 1995, é promulgada a Lei $n^{\circ}$ 9.140/95, a qual tinha como base um dossiê organizado por familiares de desaparecidos políticos e que continha um Anexo que listava um total de 136 pessoas desaparecidas

\footnotetext{
77 BRASIL. Secretaria Especial de Direitos Humanos. Comissão Especial sobre Mortos e Desaparecidos Políticos. Direito à Memória e à Verdade. Brasília: Secretaria Especial dos Direitos Humanos da Presidência da República, 2007. p. 22.

${ }^{78}$ Ibid. p. 27.

${ }^{79}$ Ibid. p. 28.

${ }^{80}$ Ibid. p. 31.
} 
durante o período de ditadura militar. Deste número, sessenta e uma pessoas seriam apontadas como ex-membros da Guerrilha do Araguaia nos anos de 1972 à 1974. Nesse gesto, o Estado brasileiro reconheceu o desaparecimento de todas essas pessoas e, ainda, criou a Comissão Especial sobre Mortos e Desaparecidos Políticos, a qual teria como objetivo reconhecer e localizar as pessoas desaparecidas que não estavam relacionadas no Anexo da lei. ${ }^{81}$

\section{c) As violações à Convenção Americana pertinentes ao Caso}

Diante das alegações apresentadas pela Comissão Interamericana no Caso Araguaia, é possível fazer uma breve análise das violações que supostamente teriam sido realizadas pelo Estado brasileiro, ressaltando o desafio que pode representar para a Corte Interamericana de Direitos Humanos o seu pronunciamento acerca de determinadas violações e a importância de que o Tribunal se pronuncie sobre a Lei de Anistia e sobre o contexto de ditadura militar no Brasil pela primeira vez.

A Comissão listou diversos artigos pelos quais o Estado brasileiro deve ser responsabilizado internacionalmente na demanda do Caso Araguaia. Neles estão incluídos os arts. $3^{\circ}$ (reconhecimento da personalidade jurídica), $4^{\circ}$ (direito à vida), $5^{\circ}$ (direito à integridade pessoal), $7^{\circ}$ (direito à liberdade pessoal), $8^{\circ}$ (garantias judiciais), 13 (liberdade de expressão) e 25 (proteção judicial), todos eles combinados com os arts. 1.1 e $2^{\circ}$, que tratam de obrigações gerais de respeito e garantia dos direitos previstos no corpo da Convenção America sobre Direitos Humanos.

\section{c.i) Arts. $3^{\circ}, 4^{\circ}, 5^{\circ}$ e $7^{\circ}$ da Convenção Americana}

A Comissão alegou em sua demanda a violação dos arts. $3^{\circ}$ (reconhecimento da personalidade jurídica), $4^{\circ}$ (direito à vida), $5^{\circ}$ (direito à

\footnotetext{
${ }^{81}$ CIDH. Op. Cit. Párr. 86
} 
integridade pessoal) e $7^{\circ}$ (direito à liberdade pessoal) c/c arts 1.1 e $2^{\circ}$ (obrigações gerais) da Convenção em razão do desaparecimento forçado das vítimas.

Cabe enfatizar que o Brasil não tem tipificado em seu ordenamento jurídico interno o crime de desaparecimento forçado e, além disso, o país não ratificou a Convenção Americana sobre o Desaparecimento Forçado de Pessoas de 1994 ou a Convenção Internacional para Proteção de todas as Pessoas contra o Desaparecimento de 2007.

Neste contexto, a Comissão enfatiza o fato da Corte considerar de forma agravada esta violação quando o desaparecimento forçado faz parte de um padrão sistemático ou prática aplicada ou tolerada pelo Estado ${ }^{82}$, o que pode vir a ser considerado o caso da ditadura militar no Brasil.

A argumentação da Comissão sobre o desaparecimento forçado leva a conclusão de que o Estado teria violado também o art. $3^{\circ}$ da Convenção, que fala do reconhecimento da personalidade jurídica. Tal violação decorreria do fato de que não seria possível estabelecer a extinção da personalidade jurídica de uma pessoa desaparecida. Além disso, o fato da pessoa permanecer desaparecida impede que ela interponha qualquer ação legal sobre o exercício de seus direitos. ${ }^{83}$

Consta ainda na demanda a violação do art. $5^{\circ}$ da Convenção também com relação aos familiares das vítimas, em razão do sofrimento causado pelo desaparecimento e morte de seus familiares, conforme vem sendo determinado pela Corte há muitos anos em sua jurisprudência.

\section{c.ii) Arts. $8^{\circ}$ e 25 c/c 1.1 e $2^{\circ}$ da Convenção}

A Comissão pede em sua demanda que recaia sobre o Brasil a responsabilização internacional pela violação dos arts. $8^{\circ}$ e $25 \mathrm{c} / \mathrm{c}$ arts $1.1 \mathrm{e}$ $2^{\circ}$ da Convenção, tendo em vista que o Brasil, por meio da lei de anistia, impediu a investigação e sanção dos responsáveis por graves violações dos

\footnotetext{
${ }^{82}$ Ibid. Párr. 161.

${ }^{83}$ Ibid. Párr. 212.
} 
direitos humanos ao não ser garantida uma proteção judicial adequada e por ter sido disponibilizado o acesso a um recurso simples e rápido para as vítimas. Conforme entendimento sedimentado pela Corte, as leis de anistia conduzem ao desamparo das vítimas e à perpetuação da impunidade.

A violação desses artigos não se deve tão-somente às ações de natureza penal que não puderam ser ajuizadas em razão da existência de uma lei de anistia, mas também em razão do lapso temporal exagerado e injustificado em que correram as ações não-penais impulsionadas pelos familiares das vítimas para conhecer a verdade.

Cumpre lembrar que na oportunidade do Caso Bairros Altos, em Voto Concorrente, o Juiz A. A. Cançado Trindade reiterou a responsabilidade internacional do Estado por aprovar lei contrária a Convenção e, ainda, sublinhou o caráter continuado dessas violações, o que permitia que essas leis pudessem ser avaliadas pela Corte mesmo que tivessem sido promulgadas há muitos anos. Sendo assim, não há que se falar em decurso do tempo para afastar a competência da Corte para analisar a validade de leis de auto-anistia, visto que continuam vigendo ao longo do tempo. Nas palavras do juiz:

En mi Voto Disidente en el caso El Amparo (Interpretación de Sentencia, 1997), sostuve la tesis de que un Estado puede tener su responsabilidad internacional comprometida "por la simple aprobación y promulgación de una ley en desarmonía con sus obligaciones convencionales internacionales de protección" (párrs. 22-23), - como lo son, en el presente caso Barrios Altos, las llamadas leyes de autoamnistía. Mientras dichas leyes permanecen en vigor, confórmase una situación continuada de violación de las normas pertinentes de los tratados de derechos humanos que vinculan el Estado en cuestión (en el presente caso, los artículos 8 y 25 , en concordancia con los artículos 1(1) y 2 de la Convención). ${ }^{84}$

É possível afirmar que tal interpretação está pacificada pela Corte em casos que são semelhantes ao caso brasileiro, contudo, não é certo que este entendimento se repetirá dessa vez. O que se conclui é que se adotada a interpretação normalmente ventilada pela Corte, o fato da Lei de Anistia

\footnotetext{
${ }^{84}$ Corte IDH, Caso Barrios Altos vs. Peru. Sentença de 14 de março de 2001 (fundamentação). Voto Concorrente do Juiz A. A. Cançado Trindade. Párr. 8.
} 
brasileira ter 30 anos de existência não será motivo para a sua não apreciação pelo Tribunal.

A Comissão requer a responsabilização do Estado brasileiro em relação ao art. $8^{\circ}$ e 25 da Convenção devido à violação do direito das vítimas de conhecer a verdade, a qual alega não ser de conhecimento da sociedade pela ausência de procedimentos investigatórios que esclarecessem as violações ocorridas durante o período ditatorial.

A Corte Interamericana, ao contrário do que pediu a Comissão em outros casos relacionados ao direito à verdade no Sistema, não consagrou ainda a violação deste direito conjuntamente com o art. 13 da Convenção, argumentando que ele estaria compreendido na proteção já existente dos arts. $8^{\circ}$ e 25 . De qualquer forma, é interessante o pronunciamento sobre o direito à verdade tendo em vista que este não tem previsão expressa na Convenção Americana.

A discussão do direito à memória e verdade tem muito valor nos casos de promulgação de leis de auto-anistia. É com base neste direito que a Corte constrói a sua argumentação de que o Estado deve afastar qualquer obstáculo processual que impeça a investigação, processamento e sanção dos responsáveis para a proteção do indivíduo e da coletividade. Portanto, apesar de a Comissão não ter repetido a postura de alegar a violação dos arts. $8^{\circ}$ e 25 conjuntamente com o art. 13 da Convenção para que a Corte Interamericana determine a violação do direito à verdade, percebe-se ainda uma boa oportunidade para a jurisprudência do Tribunal avançar neste sentido.

Caso entenda que este direito merece atenção especial e é mais amplo do que a proteção contida nesses dois últimos artigos, o Caso Araguaia poderia trazer novos parâmetros para a proteção do direito à verdade, contextualizando-o melhor no período em que toda a América Latina passava por um período de autoritarismo e de violência deliberada e tornando-o objeto de proteção também do art. 13 da Convenção Americana. 
A fim de demonstrar a importância do debate acerca do direito à verdade nos casos de leis de auto-anistia, cumpre lembrar que no Caso Bairros Altos o Estado peruano não apenas reconheceu a sua responsabilidade internacional pelos atos perpetrados por agentes do Estado durante a ditadura militar, mas também declarou diante de uma instância internacional que reconhecia fazer parte da reparação das vítimas o direito à verdade e o direito à justiça, conforme declaração a seguir:

...[L]a estrategia gubernamental en materia de derechos humanos parte de reconocer responsabilidades, pero más que nada de proponer fórmulas integrales de atención a las víctimas en relación a tres elementos fundamentales: el derecho a la verdad, el derecho a la justicia y el derecho a obtener una justa reparación ${ }^{85}$.

A Lei de Anistia vige no Brasil simultaneamente a outras leis que permitem o sigilo de documentos em poder do Estado. Dessa forma, apesar de vermos muitas pessoas sendo indenizadas por terem sofrido algum dano durante o período ditatorial, ainda vemos que individual e coletivamente o direito à verdade não é protegido, visto que os processos judiciais contra agentes do Estado daquela época não são instaurados.

Podemos afirmar que, ao contrário reconhecimento do Estado peruano no Caso Bairros Altos, durante todo esse período a verdade não foi tida como forma de reparação das vítimas aos olhos do Estado brasileiro.

A Corte Interamericana há muito estabeleceu que o Estado, a fim de dar cumprimento aos arts. $8^{\circ}$ e 25 c/c 1.1 e $2^{\circ}$ do Pacto de São José, deve realizar o controle de convencionalidade de suas leis. Isso nada mais é do que a obrigação de avaliar se uma lei promulgada internamente se adéqua aos parâmetros de proteção dos direitos humanos previstos na Convenção Americana. Caso não se adéqüe, é dever do Estado não mais dar aplicabilidade àquela lei e afastá-la de seu ordenamento jurídico.

No Caso Almonacid Arellano, também um caso sobre lei de autoanistia, ficou decidido da seguinte forma:

\footnotetext{
${ }^{85}$ Ibid. Párr. 35.
} 
La Corte es consciente que los jueces y tribunales internos están sujetos al imperio de la ley y, por ello, están obligados a aplicar las disposiciones vigentes en el ordenamiento jurídico. Pero cuando un Estado ha ratificado un tratado internacional como la Convención Americana, sus jueces, como parte del aparato del Estado, también están sometidos a ella, lo que les obliga a velar porque los efectos de las disposiciones de la Convención no se vean mermadas por la aplicación de leyes contrarias a su objeto y fin, y que desde un inicio carecen de efectos jurídicos. En otras palabras, el Poder Judicial debe ejercer una especie de "control de convencionalidad" entre las normas jurídicas internas que aplican en los casos concretos y la Convención Americana sobre Derechos Humanos. En esta tarea, el Poder Judicial debe tener en cuenta no solamente el tratado, sino también la interpretación que del mismo ha hecho la Corte Interamericana, intérprete última de la Convención Americana ${ }^{86}$.

Portanto, como estabelecido no trecho acima, o Estado, mediante a atividade jurisdicional, deve manter a sua legislação interna não somente de acordo com a Convenção Americana, mas também em acordo com a interpretação que a Corte Interamericana determina. Os juízes estão sob o império da lei e, tendo o Estado ratificado um tratado, não podem aplicar legislação contrária à finalidade da norma internacional.

Dessa forma, se fosse feito um controle de convencionalidade pelo Estado brasileiro, os tribunais nacionais deveriam levar em consideração os demais precedentes da Corte Interamericana a respeito de leis de autoanistia para afastá-la do seu ordenamento jurídico interno, sob pena de responsabilização internacional.

Hoje a Lei de Anistia no Brasil (Lei no 6.683/79) é alvo de Ação de Descumprimento de Preceito Fundamental (ADPF $n^{\circ} 153$ ) ajuizada perante o Supremo Tribunal Federal pelo Conselho Federal da Ordem dos Advogados do Brasil. A ADPF $n^{\circ} 153$ visa a esclarecer a controvérsia com relação a interpretação do art. $1^{\circ}, \S 1^{\circ}$ da Lei, que estende a anistia aos "crimes de qualquer natureza relacionados com crimes políticos".

A Ordem dos Advogados do Brasil questiona a interpretação de que os crimes cometidos pelos militares, tal qual a tortura, o abuso sexual, o atentado violento ao pudor etc. possam ser considerados crimes conexos ou relacionados aos crimes políticos. Para o Conselho Federal da OAB, tal

\footnotetext{
${ }^{86}$ CIDH. Caso Almonacid Arellano vs. Chile. Sentença de 26 de setembro de 2006. Párr.124.
} 
interpretação viola o princípio da igualdade perante a lei. Além disso, o Conselho alega que a Lei de Anistia viola também o compromisso do Estado em não ocultar a verdade, visto que permitiu que as vítimas da ditadura "pudessem identificar os seus algozes, os quais, em regra,

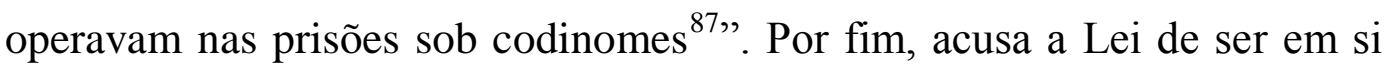
uma afronta aos princípios democrático e republicano, levando em consideração a forma como foi editada e promulgada, corroborando o caráter de auto-anistia fixado pela Corte Interamericana; e também uma afronta ao princípio da dignidade da pessoa humana, dizendo que a dignidade das vítimas foi usada como "moeda de troca em um acordo político $^{88, "}$ que sequer existiu de fato.

O julgamento da ADPF 153 demonstra-se uma oportunidade para o Supremo Tribunal Federal realizar o controle de convencionalidade da Lei de Anistia e também uma preciosa oportunidade para que a Corte Interamericana e a jurisdição interna dialoguem, tendo em vista que ambos os casos (ADPF e Caso Araguaia) estão em curso ao mesmo tempo.

\section{c.iii) Art. 13 c/c art. $2^{\circ}$ da Convenção Americana}

$\mathrm{O}$ art. 13 da Convenção trata da utilização do critério da segurança nacional para a limitação do acesso à informação. É nítido no caso brasileiro que o projeto dos militares para escapar de um julgamento se fez através da aprovação da Lei de Anistia e da utilização do critério da segurança nacional para impedir o conhecimento de fatos, isto é, restringir o acesso à informação.

Como demonstrado na demanda apresentada pela Comissão, o Brasil aprovou diversas leis e decretos sobre os arquivos secretos da ditadura. Em 1991 a Lei $\mathrm{n}^{\circ} 8.159$ regulamentou o direito de acesso aos documentos

\footnotetext{
87 ORDEM DOS ADVOGADOS DO BRASIL. Ação de Descumprimento de Preceito Fundamental. Disponível em <http://www.oab.org.br/arquivos/pdf/Geral/ADPF_anistia.pdf.> Acesso em: 16.11.2009.

${ }^{88}$ ORDEM DOS ADVOGADOS DO BRASIL. Ibid. p. 26.
} 
públicos, fixando um prazo de restrição a consulta que levava em conta a segurança da sociedade. O Decreto n 2.134 de 24 de janeiro de 1997 regulou a classificação, a reprodução e o acesso a documentos públicos de caráter reservado também levando em conta a segurança da sociedade. Em 2002, também via decreto, os prazos de confidencialidades dos documentos foram ampliados.

Tal restrição ao acesso à informação foi utilizada nos casos em que o interesse era individual e nos casos em que toda a sociedade era interessada em obter informações sobre as operações de combate à subversão levada a cabo pelos militares. A proteção do indivíduo e da coletividade no acesso a esses documentos, como vimos, é indissociável.

Sabemos que a Lei de Anistia é um obstáculo ao conhecimento da verdade, mas existem outras leis vigentes hoje em âmbito interno que sustentam o segredo de documentos em poder do Estado e que se utilizam do critério da segurança da sociedade para impedir o acesso a estas informações - o que é o caso da Lei $\mathrm{n}^{\circ}$ 11.111/05 e de outros Decretos apontados na demanda. Nesse sentido a demanda do Araguaia vai além da promulgação da Lei de Anistia no Brasil, visto que a Comissão pede a violação do art. 13 da Convenção em razão da falta de acesso à informação legitimada por leis de sigilo de documentos, combinada com a violação do art. $2^{\circ}$, que trata do dever de adotar disposições de direito interno compatíveis com a Convenção Americana.

Uma breve análise da Lei $\mathrm{n}^{\mathrm{o}} 11.111 / 05$ mostra o porquê de tal incompatibilidade. $\mathrm{O}$ art. $2^{\circ}$ da Lei diz que será determinado o sigilo de documentos quando a divulgação deste ameaçar a segurança da sociedade. In verbis:

Art. $2^{\circ} \mathrm{O}$ acesso aos documentos públicos de interesse particular ou de interesse coletivo ou geral será ressalvado exclusivamente nas hipóteses em que o sigilo seja ou permaneça imprescindível à segurança da sociedade e do Estado, nos termos do disposto na parte final do inciso XXXIII do caput do art. 5o da Constituição Federal. 
Esse critério é autorizado pela Convenção Americana e, neste ponto, apenas o mau uso pelo Estado brasileiro desta limitação pode ensejar responsabilização internacional. Todavia, vimos anteriormente que a Relatoria Especial sobre Liberdade de Expressão entende que a limitação de acesso à informação fundamentada na segurança nacional deve ser referendada por uma instância judicial independente que seja capaz de fazer o juízo de ponderação entre a segurança nacional e o interesse legítimo do cidadão de ter acesso aos documentos. Apesar disso, o art. $6^{\circ}, \S 3^{\circ}$, da Lei $n^{\circ}$ 11.111/05 diz que tal revisão será feita pela Comissão de Averiguação e Análise de Informações Sigilosas, que é órgão do Poder Executivo, sem qualquer participação do Poder Legislativo ou do Judiciário.

A Lei n ${ }^{\circ} 11.111 / 05$ não é, decerto, a única que trata da restrição de acesso a documentos em poder do Estado. Para citar outros exemplos também constantes na demanda da Comissão, temos o Decreto n ${ }^{\circ} 2.134$, publicado em 24 de janeiro de 1997; e o Decreto $\mathrm{n}^{\circ} 4.552$, de 27 de dezembro de 2002. Todos foram publicados com a mesmo finalidade, mas com o agravante de que a Lei $\mathrm{n}^{\circ} 11.111 / 05$ possui "brechas que possibilitam renovação de sigilo indefinidamente ${ }^{89,}$.

A Lei $n^{\circ}$ 11.111/05 é hoje alvo de Ação Direta de Inconstitucionalidade no Supremo Tribunal Federal, apresentada pela OAB em 2007. Portanto, outra preciosa oportunidade para o diálogo entre jurisdição interna e Sistema Interamericano.

A restrição ao acesso à informação certamente não foi exclusividade do regime autoritário brasileiro, apesar de ser considerado como um dos regimes que mais colheu dados acerca das operações criminosas utilizadas como política de Estado. A negação da informação, contudo, sustentada pela ampla interpretação do conceito de segurança nacional, pode ser observada na maior parte dos países que viveram ditaduras no nosso continente.

\footnotetext{
${ }^{89}$ BRASIL. Secretaria Especial de Direitos Humanos. Op. Cit. p. 44.
} 
Levando em consideração este cenário, chama atenção o fato de a Corte Interamericana não ter desenvolvido ainda a sua jurisprudência acerca do acesso à informação ${ }^{90}$, configurando-se o Caso Araguaia um momento oportuno para que a Corte o faça.

${ }^{90}$ CEJIL. Op. Cit. p 93. 


\section{CONCLUSÃO}

A evolução da justiça transicional permitiu que houvesse uma internacionalização da sua proteção e estabeleceu de forma permanente a sua vigilância através de tribunais permanentes, os quais mudaram a relação do Estado com seus indivíduos, tendo em vista que ambos (Estados ou líderes políticos) podem estar submetidos à jurisdições internacionais em razão de graves violações aos direitos humanos, como fazem o TPI e os Sistemas Regionais de Proteção dos Direitos Humanos.

A América Latina trouxe novos mecanismos de justiça transicional, em especial no que se refere à proteção da verdade após a derrubada dos regimes ditatoriais. Como vimos, observou-se na região a criação de comissões de verdade que adequavam a necessidade de se buscar a verdade a real impossibilidade de descobrir os fatos violatórios por meio de ações penais ou cíveis contra os perpretadores de violência do período autoritário - óbice conquistado por meio de leis de auto-anistia.

Naquele momento, acreditava-se que mover processos contra perpetradores seria uma ameaça aos regimes democráticos em construção, e grande parte dos estudiosos da justiça transicional afirmava existir uma oposição entre verdade e justiça, entre processar e democratizar ou entre comissões de verdade e processos judiciais. Contudo, passado esse momento inicial de transição política, alguns países derrubaram ou afastaram a aplicação de suas leis de auto-anistia para mover processos em face de agentes ou ex-agentes do Estado, ao passo que outros países além de mover processos, também tentavam descobrir a verdade sobre as ações promovidas pelas Forças Armadas por meio de comissões de verdade.

Ao longo deste processo de implementação de uma justiça transicional na América Latina, a Comissão Interamericana de Direitos Humanos e a Corte Interamericana de Direitos Humanos estabeleceram-se como importantes órgãos de proteção da pessoa humana, conforme era o objetivo desses órgãos no momento em que foram criados pela OEA. A 
Comissão, por meio de seus relatórios de mérito e demandas, e a Corte, por meio de sua jurisprudência, principalmente nos Casos Bairros Altos, La Cantuta e Almonacid Arellano, permitiram grandes conquistas com relação à busca da verdade e da justiça, incentivando a instauração de processos e valorando positivamente os trabalhos que vinham sendo realizados pelas comissões de verdade.

Se levarmos em conta o que afirmou a Corte Interamericana sobre leis de auto-anistia, podemos presumir que o Estado brasileiro não tem realizado um controle de convencionalidade da Lei $n^{\circ} 6.683 / 79$, a Lei de Anistia. Apesar desta postura do Estado, surge nesse momento uma nova oportunidade para que o Brasil realize tal controle, tendo em vista o ajuizamento da $\mathrm{ADPF} \mathrm{n}^{\circ}$ 153, submetida à apreciação do Supremo Tribunal Federal pelo Conselho Federal da Ordem dos Advogados do Brasil.

A ADPF, que contesta a ampliação interpretativa do conceito de "crimes conexos" para beneficiar militares, surge como uma oportunidade do Estado brasileiro utilizar os precedentes estabelecidos pela Corte Interamericana, tribunal o qual reconhece a competência para o julgamento de casos contenciosos que envolvam o Estado desde 10 de dezembro 1998, e de adequar-se aos parâmetros de proteção dos direitos humanos estabelecidos pela Convenção Americana, assinada pelo Brasil em 25 de setembro de 1992.

Não podemos dar certeza de que o Caso Araguaia será ou não concluído antes do julgamento da ADPF $\mathrm{n}^{\mathrm{o}} 153$ no STF, porém, independente disso, esta é uma excelente oportunidade para o diálogo entre a jurisdição nacional e a internacional, na qual restaria afastada a aplicabilidade da Lei de Anistia para impedir a instauração de processos dos alegados responsáveis por violar os direitos humanos durante o período de ditadura militar.

Em sua evolução jurisprudencial, a Corte afirmou ainda parâmetros para a proteção da liberdade de expressão, determinando quais seriam as limitações legítimas ao gozo deste direito de acordo com a Convenção 
Americana sobre Direitos Humanos. Embora a evolução da jurisprudência sobre liberdade de expressão não tenha se desenvolvido mediante casos de leis de auto-anistia, essa questão se faz pertinente no Caso Araguaia a partir do momento em que se submete a jurisdição da Corte a promulgação e aplicação de leis que versam sobre sigilo de documentos no Brasil, as quais estão associadas ao contexto de ditadura militar tendo em vista o possível ocultamente de documentos sobre operações realizadas pelas Forças Armadas brasileiras, utilizando para tanto o argumento da "segurança da sociedade.” A Corte Interamericana, apesar de já ter se pronunciado sobre limitações à liberdade de expressão, não possui ainda nenhum precedente específico sobre leis que determinam o sigilo de documentos.

Como explicita a Comissão em sua demanda no Caso Araguaia, existem brechas na Lei 11.111/05 que permitem que documentos fiquem permanentemente em sigilo, o que já demonstra uma afronta à proteção contida no art. 13 da Convenção Americana. Portanto, caberá a Corte se pronunciar acerca desta Lei, o que se faz imprescindível para a solução dos obstáculos construídos no Brasil para ocultar informações de interesse da sociedade e dificultar a busca pela Justiça.

A exemplo do que acontece com a Lei de Anistia, a Lei 11.111/05 também está sendo questionada no STF por meio da ADI 3987-3, e, conhecidos os parâmetros de proteção à liberdade de expressão estabelecidos pela Corte Interamericana, pode o Estado brasileiro adequarse a esses parâmetros e realizar o controle de convencionalidade desta lei também. No entanto, como frisamos, o Caso Araguaia é o primeiro caso que submete à Corte uma lei que verse sobre sigilo de documentos, o que pode tornar este precedente jurisprudencial internacional ainda mais importante para o diálogo da jurisdição interna com a internacional.

A discussão do direito à verdade permeia todo este processo e somente o fato da Corte Interamericana manifestar-se acerca da busca da verdade e da justiça no Brasil já torna o Caso Araguaia um julgamento 
importantíssimo para o Brasil e para o assentamento de mecanismos de justiça transicional no continente americano.

Como vimos em votos apartados às sentenças e em demandas da Comissão e de peticionários, vem sendo cobrado ao longo dos anos o desenvolvimento da jurisprudência da Corte com relação ao direito à verdade para que se estabeleça de maneira mais clara o conteúdo de sua proteção. A Comissão chegou a alegar em alguns casos que a proteção deste direito estaria numa combinação dos arts. $8^{\circ}$ e 25 da Convenção com o art. 13 da mesma, entendimento o qual nunca foi acolhido pela Corte. No Caso Araguaia a Comissão não vinculou a suposta violação do direito à verdade ao art. 13 da Convenção, mudando a sua postura diante desses casos.

O Caso Araguaia representa desafios à Corte em todos os sentidos: (i) discute o primeiro caso sobre lei de anistia no Brasil, o único país que permanece deliberadamente aplicando uma lei como esta; (ii) desenvolve sua jurisprudência sobre direito à verdade; (iii) e é o primeiro caso em que poderá estabelecer parâmetros claros sobre leis de sigilo de documentos. Por outro lado, o Caso desafia o Estado brasileiro a alterar uma política estabelecida há 30 anos com relação às vítimas das barbáries cometidas durante a ditadura militar e, consequentemente, com relação a toda a sociedade brasileira. É uma clara discussão acerca da implementação dos mecanismos de justiça transicional de que tratamos.

A responsabilização internacional do Brasil neste caso pode nos dar a dimensão que o Sistema Interamericano de Proteção dos Direitos Humanos tem para o Estado brasileiro. Portanto, em qual medida o Brasil respeita os tratados internacionais dos quais é parte e qual a sua vontade de fazer cumprir as determinações da Corte e da OEA. O cumprimento de suas determinações não deixa de ser um desafio para a própria Corte Interamericana. Além disso, é claro, o caso é, talvez, a derradeira e mais aguardada oportunidade que as vítimas da Guerrilha do Araguaia e demais mortos e desaparecidos políticos da ditadura militar têm para alcançar a justiça depois de mais de 30 anos de impunidade. 


\section{BIBLIOGRAFIA}

BASSIOUNI, M. Cherif. The Chicago Principles on Post-Conflict Justice. (Chicago: The International Law Institute, 2007).

CEJIL, Centro pela Justiça e pelo Direito Internacional. A proteção da liberdade de expressão e o Sistema Interamericano. San José, Costa Rica: Centro por la Justicia y el Derecho Internacional, 2005. 214 p.

MELO, Carolina de Campos. Transitional Justice in South America: The Role of the Inter-American Court of Human Rights. CEJIL Review. No 5. No prelo.

SIKKINK, Kathryn; BOTH, Walling Carriel. The impact of human rights trials in Latin America, In: Journal of Peace Research Vol. 44, n. 04, 2007.

TEITEL, Ruti. The law and politics of contemporary transitional justice, In: Cornell International Law Journal 837, 2005, : Transicional Justice Genealogy. In: Harvard Human Rights

Journal 16. 2003.

TINAJERO, Salvador. Verdad y Justicia. In: Derecho Internacional de los Derechos Humanos. México D. F.: Ediciones Coyoacán, S.A. de C.V., 2006. $771 \mathrm{p}$.

Relatórios e Casos:

BRASIL. Secretaria Especial de Direitos Humanos. Comissão Especial sobre Mortos e Desaparecidos Políticos. Direito à Memória e à Verdade. Brasília: Secretaria Especial dos Direitos Humanos da Presidência da República, 2007. 500 p. 
COMISSÃO INTERAMERICANA DE DIREITOS HUMANOS. Caso Julia Gomes Lund e outros vs. Brasil. Demanda perante a Corte Interamericana de Direitos Humanos contra a República Federativa do Brasil. 26 de março de 2009.

CORTE INTERAMERICANA DE DIREITOS HUMANOS. Opinión Consultiva OC-5/85 del 13 de noviembre de 1985 (arts. 13 e 29 da Convenção Americana sobre Direitos Humanos).

: Caso Velásquez Rodríguez. Excepciones Preliminares. Sentença de 26 de julho de 1987. : Caso Bámaca Velásquez vs. Guatemala. Sentença de 25 de novembro de 2000.

: Caso A Última Tentação de Cristo (Olmedo Bustos e outros). Sentença de 5 de fevereiro de 2001.

: Caso Barrios Altos vs. Peru. Sentença de 14 de março de 2001 (fundamentação).

: Caso Herrera Ulloa vs. Costa Rica. Sentença de 2 de julho de 2004.

: Caso do Massacre de Mapiripán. Sentença 15 de setembro de 2005 . : Caso Almonacid Arellano vs. Chile. Sentença de 26 de setembro de 2006.

ORDEM DOS ADVOGADOS DO BRASIL. Ação de Descumprimento de Preceito Fundamental. Disponível em: $\langle$ http://www.oab.org.br/arquivos/pdf/Geral/ADPF_anistia.pdf $>$. Acesso em: 16.11.2009. 